\title{
Development of bioprocesses for the integral valorisation of fish discards.
}

José Antonio Vázquez ${ }^{1 *}$, Andrea Fernández-Compás ${ }^{2}$, María Blanco ${ }^{3}$, Isabel Rodríguez-Amado ${ }^{4}$, Helena Moreno ${ }^{5}$, Javier Borderías ${ }^{5}$ \& Ricardo I. PérezMartín ${ }^{4}$

${ }^{1}$ Group of Recycling and Valorisation of Waste Materials (REVAL), Marine Research Institute (IIM-CSIC). C/ Eduardo Cabello, 6, CP 36208, Vigo, Galicia - Spain.

${ }^{2}$ Instituto Nacional de Investigación y Desarrollo Pesquero (INIDEP), Paseo Victoria Ocampo N¹ Escollera Norte, C.C.175 - 7600 Mar del Plata, Argentina.

${ }^{3}$ Group of Food Biochemistry, Marine Research Institute (IIM-CSIC). C/ Eduardo Cabello, 6, CP 36208, Vigo, Galicia - Spain.

${ }^{4}$ Department of Analytical and Food Chemistry, University of Vigo, Campus As Lagoas s/n, 32004 Ourense, Spain.

${ }^{5}$ Institute of Food Science Technology and Nutrition (ICTAN). Spanish National Research Council (CSIC). C/ José Antonio Nováis, 10. 28040 Madrid. Spain.

Corresponding author: jvazquez@iim.csic.es 


\begin{abstract}
In the present work, we have developed a set of sequential and complementary alternatives to valorise five fish discards in order to recover and produce fish mince, oils, gelatins, fish protein hydrolysates (FPHs) with antioxidant and antihypertensive properties and marine peptones. In this last case, microbial bioconversion of marine peptones was studied by Pediococcus acidilacti growth, a well-known valuable lactic acid bacterium, and the concomitant production of lactic acid and pediocin SA-1. Highly digestible FPHs with a good quality of amino acids composition and antioxidant and antihypertensive properties were easily produced. In the same bioprocess, fish oils with a healthy $\omega-3 / \omega-6$ ratio were also isolated. The use of peptones derived from FPHs as bacterial media nutrient (source of organic nitrogen) led to reduction of bioproductions costs between 2-5 folds in comparison with commercial culture medium.
\end{abstract}

Keywords: fish discards; by-products valorisation; fish protein hydrolysates; bioactivities; marine peptones; Pediococcus acidilactici. 


\section{Introduction}

Fisheries have a key importance for food and economy which is evidenced by the continuous increment of worldwide fish production which reached 171 million tonnes in 2016 with a first sale value of 362 billion USD [1]. As the world population is expected to increase up to 9.2 billion by 2050 , worldwide authorities especially in advanced countries are developing new policies directed to assure the food supply and also to support a sustainable socioeconomic and environmental growth in the marine and maritime sector. Thus, sustainability is one of the main objectives of the EU Common Fisheries Policy which has addressed the wasteful practice of discarding by including the Landing Obligation (LO), which states that all vessels must keep on board and land all the catch of the species subjected to quota or minimum landing size [2]. One of the most challenging impacts of the LO is the need to find out uses for the underutilized species/sizes which have to be kept on board and shall be restricted to purposes other than direct human consumption (fish meal, fish oil, food additives, etc.) when the fish captured is below the minimum conservation reference size. Finding new uses for discards through their transformation into medium-high added-value products might help to alleviate the costs that implies the LO contributing to improve the economic performance/incomes for the different fishing sectors stakeholders.

Two main strategies are proposed in this study for the valorisation of fish discards converting these new biomasses in medium-high added value products. These are based on two of the main reasons for discarding: species with low commercial/interest value or non-quota fish species and fish under 
minimum conservation reference size. The muscle of the specimens included in the first situation (commercial fish species above minimum conservation reference sizes which for different reasons as low commercial interest, damaged, etc. have no interest to be sold in fish auctions) could be used for the development of valorisation processes aiming to the preparation of products for direct human consumption. Thus, these specimens/species might be processed to produce a new raw material (minced muscle) suitable for the preparation of different seafood products with different textures and flavors (burgers, nuggets or structured fingers) [3]. In the other hand, specimens captured below the minimum conservation reference size (MCRS), the LO specifies that it is mandatory to land them and that their use should exclude sales for direct human consumption [2]. The strategy in this case includes the biotechnological transformation of such specimens and the by-products generated in the recovery of fish mince (heads, skins and bones) for the isolation/production of molecules that could be used in a high diversity of industrial applications as nutraceuticals, pharma, food ingredients among others [4-7].

The valorisation of fish muscle proteins for food supplements and human food purposes has been previously studied [3,8-11] and also its valorisation for nonfood purposes $[8,12,13]$. The valorisation through the biotechnological transformation of fish discards to obtain valuable bio-compounds has also been previously studied [14-18].

However, and according to the main objective of the study, this is the first time in which an integral valorisation process and bioprocess has been addressed 
using five of the most recurrently discarded fish species in trawler fisheries in North-West Spain: Blue whiting (Micromessistius poutassou), Mackerel (Scombrus scombrus), Gurnard (Trigla spp), Pouting (Trisopterus luscus) and Red scorpionfish (Scorpaena scrofa). The production of ready-to-cook products intended for human consumption, valuable bio-compounds such fish protein hydrolysates, bioactive peptides, collagen/gelatin and marine peptones as nitrogen source for microbial production have been developed.

\section{Material and Methods}

\subsection{Fish material and by-products processing}

The selected fish discards (all of them captured in Atlantic North Ocean): Blue whiting (BW, Micromesistius poutassou), Mackerel (M, Scomber scombrus), Red scorpionfish (RS, Scorpaena scrofa), Pouting ( $\mathrm{P}$, Trisoreptus luscus) and Gurnard (Gu, Trigla spp.), were separated from commercial ones on board and directly conserved in ice. In port, the species were processed in the same day of landing.

Figure 1 shows all the processes carried out in the present proposal as well as the bioproducts obtained. Initially, fish were manually gutted and headed and the muscle was mechanically separated from bones and skin using a bone separator (Baader 694, Germany). Fish mince was then processed to prepare fish frozen blocks according the protocol previously reported [3]. The methods applied for the physicochemical and organoleptic characterisation of fish mince

were also described in [3]. Samples of skins with bones (SB) were collected to evaluate the production of gelatin and the rest of SB and heads and viscera 
(He) were separately homogenised by grinding and stored at $-18^{\circ} \mathrm{C}$ until use. Weights of each fraction (muscle, He and SB) were recorded and analysed in terms of yield determinations. Proximal composition of materials was performed by determination of water, ash and organic matter content [19], total lipids [20], total nitrogen [19] and total protein as total nitrogen $\times 6.25$.

\subsection{Gelatin extraction from skin by-products and chemical characterisation}

Gelatins were extracted from SB fish discard by-products following the protocol defined in Sousa et al. [18]. Briefly, SB material was cut in portions lower than 5 $x 5 \mathrm{~cm}$ and washed using a sequential combination of $0.05 \mathrm{M} \mathrm{NaOH}, 0.02 \mathrm{M}$ $\mathrm{H}_{2} \mathrm{SO}_{4}$ and $0.05 \mathrm{M}$ citric acid solutions. The number of washes was two for each solution with a water wash among the different solutions. In all cases, the relation solid:liquid was $1: 4(\mathrm{w} / \mathrm{v})$ and the washes were executed at $22^{\circ} \mathrm{C} / 50$ $\mathrm{rpm} / 30 \mathrm{~min}$. At the end of the last wash with citric acid, a gelatin-water extraction from treated SB was performed in a rotary flask employing a proportion of $1: 2(\mathrm{w} / \mathrm{v})$ at $45^{\circ} \mathrm{C} / \mathrm{slow}$ agitation/16 $\mathrm{h}$. The obtained gelatin-water solutions were mixed with active charcoal (1.5\%) for $3 \mathrm{~h}$ and centrifuged at $8000 \mathrm{~g} / 15 \mathrm{~min}$. Finally, cleaned and deodorized gelatin solutions were ovendried $\left(50^{\circ} \mathrm{C} / 72 \mathrm{~h}\right)$.

To determine the gel strength, samples were prepared by dissolving $6.67 \%$ $(w / v)$ gelatin in deionized water at room temperature for $30 \mathrm{~min}$, followed by 30 min in a water bath at $60{ }^{\circ} \mathrm{C}$ (with constant agitation). Gelatin solutions were then left to cool in a refrigerator at $4{ }^{\circ} \mathrm{C}$, for $16-18 \mathrm{~h}$, prior to texture analysis [21]. Moreover, levels of proline and hydroxyproline in gelatin solutions were 
quantified by ninhydrin reaction, using an amino acid analyzer (Biochrom 30 series, Biochrom Ltd., Cambridge, UK), according to the method of Moore et al. [22].

\subsection{Enzymatic hydrolysis of by-products and chemical analyses}

Enzyme proteolyses were carried out in a controlled pH-Stat system with a $5 \mathrm{~L}$ glass-reactor (including for hydrolysis $1 \mathrm{~kg}$ of raw material, SB or He, plus $2 \mathrm{~L}$ of distilled water) using $2 \mathrm{M} \mathrm{NaOH}$ as alkaline reagent to $\mathrm{pH}$-control. The experimental conditions were previously optimised for BW wastes (data not shown) and stablished, for all cases, as: $60.6^{\circ} \mathrm{C}, \mathrm{pH} 8.6$, agitation of $200 \mathrm{rpm}$ and 1\% (v/w) of Alcalase 2.4L (Novozymes, Nordisk, Bagsvaerd, Denmark). At the end of the hydrolysis $(4 \mathrm{~h})$, the content of the reactors was filtered $(100 \mu \mathrm{m})$ to remove bones, the liquid hydrolysates were centrifuged (15000 g/20 $\mathrm{min}$ ) to recover oils (adding a step of decantation for $5 \mathrm{~min}$ ) and the final fish protein hydrolysates (FPHs) were quickly heated $\left(90^{\circ} \mathrm{C} / 15 \mathrm{~min}\right)$ to enzyme deactivation. $\mathrm{V}_{\text {oil }}$ was defined as the percentage of oil volume recovered per solid by-product weight. The profile of fatty acids from oils was analysed by GC-chromatography after chemical methylation [23]. $\mathrm{FPH}$ were stored at $-18^{\circ} \mathrm{C}$ until analysis. The basic analysis of FPHs were: 1) total soluble protein [24], 2) total sugars [25], 3) total protein as total nitrogen x 6.25 [18], 4) proximal composition (as previously cited), 5) amino acids content (as previously cited), and 5) in vitro digestibility (pepsin method: AOAC Official Method 971.09 following the modifications suggested by Miller et al. [26]). The degree of hydrolysis ( $H$, as \%) was quantified following the $\mathrm{pH}$-Stat method [27] and the equations described in a 
previous report [15]. The data of $H$ over time were then modelled with Weibull equation [5]:

$$
H=H_{m}\left\{1-\exp \left[-\ln 2\left(\frac{t}{\tau}\right)^{\beta}\right]\right\} \quad \text { with } v_{m}=\frac{\beta H_{m} \ln 2}{2 \tau}
$$

where, $H$ is the degree of hydrolysis (\%); $t$ the time of hydrolysis (min); $H_{m}$ the maximum degree of hydrolysis (\%); $\beta$ a parameter related with the maximum slope of muscle hydrolysis (dimensionless); $v_{m}$ the maximum rate of hydrolysis $\left(\% \min ^{-1}\right)$ and $\tau$ the time required to achieve the semi-maximum degree of hydrolysis $(\mathrm{min})$. The factor of digestion/liquefaction $\left(\mathrm{V}_{\mathrm{dig}}\right)$ of raw material to liquid phase was defined (in \%, v/w) as the volume of final FPH produced after bones and oil separation and enzyme deactivation per the sum in weight of the solid raw material, initial water and alkalis added for hydrolysis process.

Marine peptones from SB (SBP) and $\mathrm{He}(\mathrm{HeP})$ were defined as the liquid phases obtained after the sterilisation $\left(121^{\circ} \mathrm{C} / 15 \mathrm{~min}\right)$ and centrifugation (15000 g/20 min) of each FPH.

\subsection{Antihypertensive activity of FPHs}

The antihypertensive activity of FPHs was determined using N-[3-(2-Furyl) acryloyl]-L-phenylalanyl-glycyl-glycine (FAPGG) as substrate according the modifications reported by Estévez et al. [28]. Angiotensin I-converting enzyme (ACE) inhibitory activity $\left(I_{A C E}\right)$ of hydrolysates (prepared at concentration of 1 $\mathrm{g} / \mathrm{L})$ was calculated as a function of the average slope of decrease in 
Absorbance with time and expressed as percentage inhibition of the enzyme, according to the following expression:

$$
I_{A C E}(\%)=\left(1-\frac{r A_{h}}{r A_{c}}\right) \times 100
$$

where $I_{A C E}$ is the ACE-inhibitory capacity (\%), $r A h$ is the slope of decrease in Absorbance at $340 \mathrm{~nm}$ in the presence of inhibitor (hydrolysate), and $r A c$ is the slope decrease in Absorbance at $340 \mathrm{~nm}$ in the absence of inhibitor (control). The protein-hydrolysate concentration that generates a $50 \%$ of $I_{A C E}\left(I C_{50}\right)$ was calculated by fitting the dose-response relationship between $I_{A C E}$ vs. hydrolysate to a Weibull equation [6]:

$$
I_{A C E}=K\left\{1-\exp \left[-\ln 2\left(\frac{C}{I C_{50}}\right)^{a}\right]\right\}
$$

where $K$ is the maximum $I_{A C E}(\%), C$ is the protein-hydrolysate concentration $(\mu \mathrm{g} / \mathrm{mL}), I C_{50}$ is the concentration for semi-maximum $I_{A C E}(\mu \mathrm{g} / \mathrm{mL})$, and $a$ is the form parameter related to the maximum slope of the function (dimensionless).

\subsection{Antioxidant $(A O)$ determinations of FPHs}

\subsubsection{1,1-Diphenyl-2-picryhydrazyl (DPPH) radical-scavenging capacity}

The antioxidant activity, of samples with $1 \mathrm{~g} / \mathrm{L}$ of soluble protein, as radicalscavenging capacity was determined with $\mathrm{DPPH}$ as a free radical by the 
microplate method described by Prieto et al. [29]. The DPPH activity was calculated as a percentage of DPPH discoloration using the equation:

$$
\operatorname{DPPH}(\%)=\frac{\left(A_{\text {control }}\right)_{t=1 h}-\left(A_{\text {hydrolysate }}\right)_{t=1 h}}{\left(A_{\text {control }}\right)_{t=1 h}} \times 100
$$

where $A_{\text {sample }}$ is the Absorbance at $515 \mathrm{~nm}$ of the DPPH in the presence of the hydrolysate, and $A_{\text {control }}$ is the Absorbance at $515 \mathrm{~nm}$ of the DPPH solution in its absence.

\subsubsection{ABTS bleaching method}

The ABTS (2,2-azinobis-(3-ethyl-benzothiazoline-6-sulphonic acid) radical scavenging activities were evaluated according the protocol previously reported [29].

\subsubsection{Crocin bleaching method}

The kinetics of the crocin $(\mathrm{Cr})$ bleaching assay were based on the protocol optimized by Prieto et al. [30] using crocin and 2,2 -azobis-2-amidinopropane $(\mathrm{AAPH})$ as reagents and carried out in microplate spectrophotometer.

In these last two methods the kinetics of reaction were performed in triplicate. For each series, reversed curves were obtained by subtracting the Absorbance at time $t$ from the Absorbance value at time 0 . The area under the curves (AUC) can be calculated by the following function [6]: 


$$
A \cup C=\left(y_{0}+2 y_{1}+2 y_{2}+\ldots+2 y_{n-2}+2 y_{n-1}+y_{n}\right) \frac{\Delta t}{2}
$$

where $y_{0}$ to $y_{n}$ are the $n+1 y$-values defining the curve, and $\Delta t$ is the sampling interval (min). Calculated areas of controls concentrations (Trolox for $\mathrm{Cr}$ and $\mathrm{BHT}$ for ABTS) were fitted by linear regression. Calculated areas of hydrolysate dilutions were plotted against controls (equivalents) and the antioxidant activities (as equivalents in $\mu \mathrm{g}$ of $\mathrm{BHT}$ or Trolox per $\mathrm{mL}$ of hydrolysate) were defined by means of the $E C_{50}$ values obtained by fitting the data of equivalents versus sample concentrations to a similar Weibull equation [3] (but replacing $I C_{50}$ by $\left.E C_{50}\right)$. All AO determinations were done in triplicate and concentration initial of hydrolysate was standardised at $1 \mathrm{~g} / \mathrm{L}$.

\subsection{Microbial bioconversion of marine peptones}

Pediococcus acidilactici NRRL B-5627 was used in the evaluation of SBP and HeP and Carnobacterium piscicola CECT 4020 (Spanish Type Culture Collection) was the indicator microorganism for bacteriocin (Pediocin SA-1) bioassays. Stock cultures were stored $20^{\circ} \mathrm{C}$ on Man, Rogosa and Sharpe medium (MRS) with $25 \%$ glycerol. Inocula $(0.5 \%, \mathrm{v} / \mathrm{v})$ consisted of cellular suspensions from $16 \mathrm{~h}$ aged in MRS (incubated at $30^{\circ} \mathrm{C}$ ) and adjusted to an optical density-OD (700 nm) of 0.900 .

The composition of the culture media is shown in Table S1 (supplementary material) employing MRS commercial medium (Pronadisa, Spain) as control. In all cases, initial $\mathrm{pH}$ was adjusted to 7.0 with $5 \mathrm{M} \mathrm{NaOH}$ and solutions sterilised at $121^{\circ} \mathrm{C}$ for $15 \mathrm{~min}$. Micro-organisms were grown, by duplicate, in $300 \mathrm{~mL}$ 
Erlenmeyer flasks with $180 \mathrm{~mL}$ of medium at $30^{\circ} \mathrm{C}$ and orbital agitation of 200 rpm. At pre-established times, each culture sample was divided into two aliquots.

The first aliquot was centrifuged at $4750 \mathrm{~g}$ for $15 \mathrm{~min}$ and the sediment resuspended in distilled water to an adequate dilution for measuring OD at 700 $\mathrm{nm}$. This OD was transformed in dry weight (biomass in $\mathrm{g} / \mathrm{L}$ ) using a calibration curve. The supernatant was used for the measurement of reducing sugars [31], soluble protein [24], lactic and acetic acids. These organic acids were quantified by HPLC analysis (refractive index detector), using an ION-300 column (Transgenomic, USA) with $6 \mathrm{mM} \mathrm{H}_{2} \mathrm{SO}_{4}$ sulphuric acid as mobile phase (flow= $0.4 \mathrm{~mL} / \mathrm{min}$ ) at $65^{\circ} \mathrm{C}$. Methods for the extraction and quantification of bacteriocins were previously described in detail $[32,33]$, using C. piscicola as indicator. All assays and analyses were carried out in duplicate.

Kinetic profiles of $P$. acidilactici growth and metabolic production were modelled by the logistic equation [34]:

$$
P=\frac{P_{m}}{1+\exp \left[2+\frac{4 v_{P}}{P_{m}}\left(\lambda_{P}-t\right)\right]}
$$

where, $P$ is the concentration of the corresponding bioproduction ( $X$ : biomass, La: lactic acid, $A$ : acetic acid or $B T$ : bacteriocin) (in $g / L$ for $X, L a, A$; and Bacteriocin Unit/mL, BU/mL, for $B T) ; t$ is the time of culture $(\mathrm{h}) ; P_{m}$ is the maximum concentration of each bioproduction in the asymptotic phase $(\mathrm{g} / \mathrm{L}$ or 
$\mathrm{BU} / \mathrm{mL}) ; v_{P}$ is the maximum bioproduction rate $\left(\mathrm{g} \mathrm{L}^{-1} \mathrm{~h}^{-1}\right.$ or $\left.\mathrm{BU} \mathrm{mL}^{-1} \mathrm{~h}^{-1}\right)$; and $\lambda_{P}$ is the lag phase of the bioproductions (h).

\subsection{Numerical and statistical analyses}

Data fitting procedures and parametric estimations were carried out by minimisation of the sum of quadratic differences between observed and modelpredicted values, using the non-linear least-squares (quasi-Newton) method provided by the macro 'Solver' of the Microsoft Excel spreadsheet. Confidence intervals from the parametric estimates (Student's t test) and consistence of mathematical models (Fisher's F test) were evaluated by "SolverAid" macro. The significance of comparisons between samples was analysed by ANOVA with a significance level of $p<0.05$.

\section{Results and Discussion}

To accomplish the valorisation strategy of fish discards, the yields of the different by-products, from entire specimens, were calculated. The percentages of He manually separated were (average \pm confidence interval): $45 \pm 15 \%$ for RS, $42 \pm 10 \%$ Gu, $21 \pm 15 \%$ for $M, 30 \pm 10 \%$ for $P$ and $19 \pm 14 \%$ for BW. For its part, the percentage of muscle recovered from mechanical separation was near or higher than $50 \%$ of total fish weight for all considered species except from the RS that due its morphology and high contain of bones lead to a more inefficient operation. Thus, the percentage of muscle was $34 \pm 2 \%$ for RS, $40 \pm 3 \%$ for $\mathrm{Gu}$, $50 \pm 4 \%$ for $M, 51 \pm 4 \%$ for $P$ and $60 \pm 4 \%$ for $B W$. Although the muscle yield is good in all species, little is yet known about the use of this raw material for the preparation of commercial different seafood products (nuggets, structured 
preparations, burgers, etc.) and even less research has been conducted in the valorisation of the other fractions recovered in this study regarding the species selected. Finally, the percentage of SB recovered resulting in (as \%) $21 \pm 6$, $18 \pm 5,29 \pm 12,19 \pm 7$ and $21 \pm 9$ for RS, Gu, M, P and BW, respectively.

\subsection{Fish mince and gelatine isolation}

With the aim of study, the valorisation potential of muscle proteins from the species selected, the mince obtained as explained in Blanco et al. [3], was subjected to physicochemical and sensory analyses and used for the preparation of restructured products. The proximate composition of the mince was similar in all species with the sole exception of mackerel mince with a higher amount of lipids. Fish mince proximate composition (Media + SD) expressed in percentage of wet weight was the following: 76.40 \pm 0.11 moisture, $1.28 \pm 0.09$ ashes, $1.25 \pm 0.01$ lipids and $16.62 \pm 0.012$ proteins for BW; $66.5 \pm 0.22$ moisture, $1.22 \pm 0.09$ ashes, $4.28 \pm 0.6$ lipids and $17.94 \pm 0.26$ proteins for $M$; $74.44 \pm 0.2$ moisture, $1.19 \pm 0.02$ ashes, $1.78 \pm 0.10$ lipids and $16.49 \pm 0.16$ proteins for RS; $74.32 \pm 0.53$ moisture, $1.19 \pm 0.02$ ashes,1.49 \pm 0.10 lipids and $17.27 \pm 0.14$ proteins for $\mathrm{Gu} ; 75.30 \pm 0.93$ moisture, $1.29 \pm 0.09$ ashes, $1.00 \pm 0.10$ lipids and $16.66 \pm 0.07$ proteins for $P$. The protein native structure after 6 months of frozen storage was analysed by means of DSC analysis and revealed a good-quality mince comparable with that found in Alaska Pollock surimi (denaturation enthalpy data $(\mathrm{J} / \mathrm{g} \mathrm{dm})$ varied between $0.29-0.61$ in non-washed mince and between $0.39-0.67$ in washed mince [3]). Regarding the functional properties of minces, no rancid flavour was detected in any sample although lipid oxidation increased after 6 months of frozen storage especially in mackerel mince (from 
7.3 $\mathrm{mg} \mathrm{MDA} / \mathrm{kg}$ to $11.4 \mathrm{mg} \mathrm{MDA} / \mathrm{kg}$ ). All mince samples showed good sensory acceptability in terms of general appearance (scores: 5.2, 5.1, 5.3, 6.04 and 4.6 for BW, M, RS, Gu and P, respectively), texture (scores: 5.99, 6.04, 5.41, 5.07 and 5.18 for BW, M, RS, Gu and P, respectively) and taste (scores: 4.88, 4.25, 4.98, 5.71 and 4.29 BW, M, RS, Gu and P, respectively), with the highest scores corresponding to BW, M and Gu. From the frozen blocks of mince elaboration test were carried out in order to obtain a final restructured product suitable to the consumer and marketable in different preparations as nuggets, hamburguers or fingers. The obtained results regarding organoleptic characteristics were very positive among end users and consumers with the highest scores (between 4.5 and 5) awarded to "fingers" of pouting and red scorpionfish, and above all mackerel burguers. The results showed an agetrend preference: older people preferred burgers and youngers preferred fingers and nuggets [3].

In Table 1, the results of gelatin production are summarised including the yield of extraction, the strength of gels and the percentage of proline + hydroxyproline. The recovery of gelatinous solution from gurnard was null and the yield of extraction in the rest of cases was not very satisfactory with values lower than $1 \%$ (w/w wet skin), very inferior data in comparison to the amount of gelatin produced when tuna and blue shark skins are processed using the same protocol [18]. However, quite similar amount of gelatins were isolated from mackerel and blue whiting skins $(0.86 \%$ and $1.5 \% \mathrm{w} / \mathrm{w}$ wet weight basis, respectively) treated with alkalis and organic acids $[35,36]$. On the other hand, the extraction of gelatin from mackerel and blue whiting bones achieved yields 
of $4 \%$ and $2 \%$ respectively, using a combination of enzymatic proteolysis, chemical demineralisation and hot water extraction [37]. In the case of gurnard, the lack of gelatin may be due to that extraction method was too aggressive and not very optimal for this substrate. No comparison can be made from literature data for pouting, gurnard and red scorpionfish gelatins because skins, as source of gelatins, from these species have not been explored yet.

Additionally, the gelatinous solutions did not gel perfectly, in fact only gelatin from pouting showed a very low gel strength $(16.1 \pm 0.6$ bloom). In the other ones were not possible to measure the gel strength due to inability to harden. Khiari and co-workers [36] reported higher values of gel strength (80 g) for gelatin from mackerel skin pre-treated with $\mathrm{NaOH}$ and acetic acid. In addition, the levels of proline plus hydroxyproline in the current work are in agreement with those found in Khiari et al. [36].

\subsection{Production of skin and head enzymatic hydrolysates}

The corresponding products recovered from SB and He hydrolysis are defined in Figure 1 and the mass/volume balance reported in Table 2. After hydrolysis, clean bones were separated by filtration and the percentage of these materials found ranged between 14-29\% for SB and 13-18 for He. Especially significant is the high amount of bones that RS presents. The percentage of digestion/liquefaction ( $\mathrm{V}_{\text {dig }}$ ) of solid material (including bones) by Alcalase was higher than 84\% (He_Gu) reaching 98\% in SB_BW. In general, the value of $\mathrm{V}_{\text {dig }}$ was significantly larger for SB by-products than He by-products $(p<0.05)$. In the same bioprocess (Figure 1), the amount of oil recovered was null for SB_BW, 
SB_P and He_P, low for SB_RS and He_BW and remarkable for the rest of byproducts and fish discards. The lack of oil in those samples could be due to the low initial quantity of oil present in the pouting by-products (pouting is a very little fatty species) and/or the low capacity of the protocol employed to separate oils when micro and macroemulsions are formed in the hydrolysis. As expected from being a fatty species, mackerel by-products led to the highest volume of oil extracted (more than $10 \% \mathrm{v} / \mathrm{w}$ ). Table 3 shows the composition of fatty acids in the oil samples (less in the case of SB_RS that was negligible). In all cases, the predominant fatty acids were, in this order, oleic acid, palmitic acid, DHA and EPA. In this context, the percentage of DHA was higher than $7.5 \%(16.7 \%$ for He_BW), the sum of EPA and DHA greater than $12.5 \%$ (25\% for He_M) and the ratio $\omega-3 / \omega-6$ higher than 5.6 . This last result confirms the valuable and excellent composition of the present fish oils easily recovered from fish discards wastes for potential human applications in healthy diets [38-40]. In the same way, other authors have observed similar DHA and EPA values in oil samples obtained from whole individuals of $S$. scombrus but also lower levels of oleic and palmitic acid $[41,42]$.

Regarding to the total protein concentration of FPHs, differences were found when type of by-product (SB and He) and type of species are compared. Higher levels of Pr-tN are observed in SB_FPHs compared to He_FPHs $(p<0.05)$. Hydrolysates from SB_BW and SB_P led to the highest protein content. In all situations, almost all protein determined was soluble protein since Lowrymethod data were very similar than those obtained by total nitrogen and total sum of amino acids. In vitro digestibilities (Dig) of FPHs were excellent (more 
than $90 \%$, Table 2) and the composition of amino acids revealed the presence of essential ones (Ile, Leu, Val, Lys, Met, Phe, Thr, His and Arg) in remarkable proportion (Table S2, supplementary material). Both data, Dig and amino acids balance, suggests that FPHs produced here could be an appropriate ingredient for aquaculture feed and pet food diets as substitute of fish meal [43-45]. They are also an excellent source of amino acids as recommended by World Health Organisation for daily human consumption [46].

From the point of view of the hydrolysis kinetics, the hyperbolic experimental profiles were perfectly modelled by Weibull equation (1) (Figure 2). The coefficients of determination were higher than 0.990 and the robustness and consistency of fittings was corroborated in all cases $(p<0.005)$ (Table 4). In addition, all kinetic parameters were always significant for $\alpha=0.05$. The highest hydrolysis, determined by the values of $H_{m}$, were generally found for $\mathrm{He}$ substrates being the by-products from pouting discards the most hydrolysable. The numerical data of $\tau$ were lower for $\mathrm{He}$ in comparison with SB $(p<0.05)$ and the maximum rate of hydrolysis $\left(v_{m}\right)$ was significantly higher in He-hydrolysis than SB-hydrolysis $(p<0.05)$. As mentioned, the references to the enzyme processing of the present fish discards are scarce (some works of BW and M) or null in most cases but only one article shows a complete description of the hydrolysis kinetics, although without a modelling approach. In that report, Pérez-Gálvez and co-authors [47] studying the hydrolysis of whole body of BW (captured in West Mediterranean Sea) assisted by a combination of Alcalase 2.4L and Trypsin, generated similar hyperbolic patterns and similar maximum 
degrees of hydrolysis (ranging 13-16\%) to those displayed in Figure 2 and data defined in Table 4.

\subsection{In vitro bioactivities of FPHs}

The samples of hydrolysates at the end of the enzyme process ( $4 \mathrm{~h}$ ) were also analysed quantifying the antioxidant activity (by DPPH, ABTS and Crocin methods) and the ACE activity as percentage of inhibition and as the value of $I C_{50}$ [48]. The values of DPPH scavenging activity were not very promising with percentages inferior to $48 \%$, being SB_RS and SB_Gu the FPHs that led to highest activities. However, He_RS and He_Gu showed the lowest DPPH capacity (less than 7\%) (Table 5). These data were in concordance with the other two AO protocols: the FPHs that led to the best and worst results were also SB_RS and He_RS, respectively, in both ABTS and Crocin methods. Altough we consider that $\mathrm{AO}$ activities were generally low when they are compared with synthetic and natural antioxidants [49-52] and other bioactive peptides produced from marine waste effluents and fish by-products $[6,15,16,53-56]$, our levels are in the same order of magnitude than those found by FPHs from whole BW obtained using Alcalase [57] and from head RS hydrolysed with Trypsin and Flavourzyme [58].

On the other hand, ACE results are summarised in Table 6. The inhibition data were ranging between 0 and $77 \%$. Various FPHs did not reveal antihypertensive activity (He_BW, He_Rs and He_Gu) and SB_Rs, SB_P and SB_Gu reached levels higher than 65\%. FPHs from SB were significantly more active than FPHs from He $(p<0.05)$. In concordance with these values, FPHs 
from RS muscle and BW fillets obtained applying a protease isolated from fungi (Penicillium digitatum) and Alcalase, respectively, led to a $50 \%$ and $75 \%$ of $I_{\text {ACE }}$ in each case $[59,60]$. For the calculation of $I C_{50}$ in our FPHs (from equation (3)), only the samples that achieved at least a $50 \%$ of ACE inhibition were assayed in the dose-response experiments (Table 6). SB_Gu showed the largest activity (152 $\mu \mathrm{g} / \mathrm{mL})$ following by SB_P $(211 \mu \mathrm{g} / \mathrm{mL})$ and SB_RS $(226 \mu \mathrm{g} / \mathrm{mL})$. These activites were better than those reported for head RS $(0.489 \mathrm{mg} / \mathrm{mL})$, fillets BW (1.34 $\mathrm{mg} / \mathrm{mL})$ and muscle RS $(970 \mu \mathrm{g} / \mathrm{mL})$ [58-60]. Further studies of purification should be performed to isolate and characterise the peptides responsibles of antihypertensive activity.

\subsection{Bioconversion of marine peptones by P. accidilactici}

Although we have already commented the potentiality of our FPHs as ingredient of aquaculture feed, pet food diets or even human foods, in the present study they were evaluated as source of proteins, peptides and free amino acids (peptones) for the formulation of low cost media for the growth of a well-known lactic acid bacterium, $P$. accidilactici (producer of a potent bacteriocin: pediocin SA-1) [61]. The bacterial kinetics on the media formulated with SBP and HeP, together with MRS as control medium, are illustrated in Figure 3.

In both sets of kinetics, cultures with SBP and HeP, the biomasses of $P$. acidilactici were higher in low-cost media than MRS control. Logistic equation (6) demonstrated very good agreement to simulate the sigmoid experimental kinetics of growth, lactic acid and pediocin productions with coefficients of determination ranging $0.980-0.999$ (Table 7 ). The data of acetic acids were 
lower than $0.4 \mathrm{~g} / \mathrm{L}$ and the experimental run patterns were very erratic but also adjustable to equation (6) in many cases.

The values of $H_{m}$ (maximum growth as dry weight of biomass) in cultures using SBP samples were statistically higher than HeP and MRS $(p<0.05)$ being SBP_BW and SBP_RS the peptones that induced the best biomass productions. However, both maximum growth rates $\left(v_{x}\right)$ and the lag phase of growths $\left(\lambda_{x}\right)$ did not show significant difference between media $(p>0.05)$. In general, the yields of biomass production regarding nutrient uptakes (glucose and proteins) was higher employing alternative peptones than the commercial ones including in MRS. The maximum productions of lactic acid $\left(L a_{m}\right)$ were statistically similar in all media (SBP_RS, SBP_P and HeP_M as the best options) less in HeP_BW and HeP_P in which the values were lower $(p<0.05)$ than other ones. Lag phases and maximum rates of lactic acid productions were statistically indistinguishable among cultures. In the case of pediocin, MRS was always the most productive and effective nutrient formulation and SBP most adequate source of organic nitrogen than HeP (excluding the peptone from HeP_Gu).

These results are in agreement with the fermentative data observed when peptones from enzymatic and alkaline effluents generated in the isolation of chitin from squid pens were used in the formulation of substitutive MRS media [48]. References studying the production of peptones obtained from heads and skins of the present fish discards tested were not found. Based on the commercial prices of the glucose, yeast extract, mineral salts and commercial 
peptones included in MRS medium, the costs of biomass (as $X_{m}$ ), lactic acid (as $L_{m}$ ) and pediocin (as $B T_{m}$ ) productions in the alternative media (SBP and HeP) were calculated (Figure S1, supplementary material). From this figure, we can conclude that the reduction cost was five times for the biomass production, three times for lactic acid and two times for the pediocin SA-1.

\section{Conclusions}

In the present work, a whole of alternatives and bioprocesses have been proposed in order to valorise fish discards species. In this context, the production of fish mince (previously reported), the recovery of fish oils, the extraction of gelatins, the production of fish protein hydrolysates and marine peptones from such substrates have been addressed. Additionally, marine peptones have been utilized, as culture media ingredient, in the production of pediocin, lactic acid and biomass from P. acidilactici. Both, fish mince and fish oil (the yields of isolation only were remarkable for SB_M, He_M, He_RS and He_Gu) can constitute a valuable source to formulate restructured fish food and nutraceuticals, respectively. The production yields and composition of FPHs from $\mathrm{SB}$ and $\mathrm{HE}$, together with the bioactivities generated, indicated the

excellent viability of this bioproduction to valorise those by-products from discards of potential usefulness as aquaculture feed ingredients. In addition, all FPHs demonstrated to be promising peptones in the formulation of novel and low-cost bacterial culture media. Developments as here proposed, following the concept of marine biorefinery, are fundamental to the integral recovery of the biomass from fishing discards complying with the objectives of circular bioeconomy. Further calculations based on energy and mass flows, life cycle 
assessment (LCA) and $\mathrm{CO}_{2}$-footprint should be performed to estimate the real sustainability of the present processes.

\section{Acknowledgements}

The authors thank to Ana Durán, Margarita Nogueira, Araceli Menduíña and Javier Fraguas for their excellent technical assistance. This research was funded by the projects iSEAS LIFE13 ENV/ES/000131 (LIFE+Programme, EU) and CVMar+i (0302_CVMAR_I_1_P, POCTEP 2015).

\section{References}

1. FAO, The State of World Fisheries and Aquaculture 2018 - Meeting the sustainable development goals, (2018).

http://www.fao.org/3/i9540en/I9540EN.pdf

2. Regulation (EU) No $13880 / 2013$ of the European Parliament and of the Council of the European Union.

3. M. Blanco, F. Domínguez-Timón, R.I. Pérez-Martín, J. Fraguas, P. RamosAriza, J.A. Vázquez, A.J. Borderías, H.M. Moreno, Valorization of recurrently discarded fish species in trawler fisheries in North-West Spain, J. Food Sci. Technol. 55 (2018) 4477-4484.

4. M. Blanco, J. Fraguas, C.G. Sotelo, R.I. Pérez-Martín, J.A. Vázquez, Production of chondroitin sulphate from head, skeleton and fins of Scyliorhinus canicula by-products by combination of enzymatic, chemical precipitation and ultrafiltration methodologies, Mar. Drugs 13 (2015) 3287-3308.

5. J.A. Vázquez, R. Caprioni, M. Nogueira, A. Menduíña, P. Ramos, R.I. PérezMartín, Valorisation of effluents obtained from chemical and enzymatic chitin production of Illex argentinus pen by-products as nutrient supplements for various bacterial fermentations, Biochem. Eng. J. 116 (2016) 34-44.

6. I.R. Amado, M.P. González, M.A. Murado, J.A. Vázquez, Shrimp wastewater as a source of astaxanthin and bioactive peptides. J. Chem. Technol. Biotechnol. 91 (2016) 793-805.

7. R.L. Olsen, J. Toppe, I. Karunasagar, Challenges and realistic opportunities in the use of by-products from processing of fish and shellfish, Trends Food Sci. Technol. 36 (2014) 144-151. 
8. H.M. Moreno, A.J. Borderías, C. Baron, Evaluation of some physicochemical properties of restructured trout and hake during cold gelation and chilled storage, Food Chem. 120 (2010) 410-417.

9. S. Egerton, S. Culloty, J. Whooley, C. Stanton, R.P. Ross, Boarfish (Capros aper): Review of a new capture fishery and its valorization potential. ICES $\mathrm{J}$. Mar. Sci. 74 (2017) 2059-2068.

10. B. Solo-de-Zaldívar, B. Herranz, A.J. Borderías, C.A. Tovar, Effect of freezing and frozen storage on restructured FISH prototypes made with glucomannan and FISH mince, Food Hydroc. 41 (2014) 233-240

11. H. Moreno, J. Carballo, J. Borderías, Raw-appearing restructured fish models made with sodium alginate or microbial transglutaminase and effect of chilled storage, Food Sci. Technol. 33 (2013) 137-145.

12. H. Bougatef, F. Krichen, F. Capitani, I.B. Amor, F. Maccari, V. Mantovani, F. Galeotti, N. Volpi, A. Bougatef, A. Sila, Chondroitin sulfate/dermatan sulfate from corb (Sciaena umbra) skin: Purification, structural analysis and anticoagulant effect, Carbohydr. Polym. 196 (2018) 272-278.

13. I. Jemil, M. Jridi, R. Nasri, N. Ktari, R. Ben Slama-Ben Salem, M. Mehiri, M. Hajji, M. Nasri, Functional, antioxidant and antibacterial properties of protein hydrolysates prepared from fish meat fermented by Bacillus subtilis A26, Proc. Biochem. 49 (2014) 963-972.

14. M. Blanco, J.A. Vázquez, R.I. Pérez-Martín, C.G. Sotelo, Hydrolysates of fish skin collagen: An opportunity for valorizing fish industry byproducts, Mar. Drugs 15 (2017) 131.

15. J.A. Vázquez, M. Blanco, A.E. Massa, I.R. Amado, R.I. Pérez-Martín, Production of fish protein hydrolysates from Scyliorhinus canicula discards with antihypertensive and antioxidant activities by enzymatic hydrolysis and mathematical optimization using response surface methodology, Mar. Drugs 15 (2017) 306.

16. I.R. Amado, J.A. Vázquez, M.P. González, M.A. Murado, Production of antihypertensive and antioxidant activities by enzymatic hydrolysis of protein concentrates recovered by ultrafiltration from cuttlefish processing wastewaters, Biochem. Eng. J. 76 (2013) 43-54.

17. J.A. Vázquez, M.P. González, M.A. Murado, A new marine medium. Use of different fish peptones and comparative study of the growth of selected species of marine bacteria, Enz. Microb. Technol. 35 (2004) 385-392.

18. S.C. Sousa, J.A. Vázquez, R.I. Pérez-Martín, A.P. Carvalho, A.M. Gomes, Valorization of by-products from commercial fish species: Extraction and chemical properties of skin gelatins, Molecules 22 (2017) 1545. 
19. AOAC, Association of Official Analytical Chemistry. Methods of Analysis., 15th ed., Washington DC, USA, (1997).

20. E.G. Bligh, W.J. Dyer, A rapid method of total lipid extraction and purification, Can. J. Biochem. Physiol. 37 (1959) 911-917.

21. M. Gómez-Guillén, P. Montero, Extraction of gelatin from megrim (Lepidorhombus boscii) skins with several organic acids, J. Food Sci. 62 (2001) 213-216.

22. S. Moore, D.H. Spackman, W.H. Stein, Chromatography of amino acids on sulfonated polystyrene resins. An improved system, Anal. Chem. 30 (1958) 1185-1190.

23. G. Lepage, C.C. Roy, Direct transesterification of all classes of lipids in a one-step reaction, J. Lipid Res. 27 (1986) 114-120.

24. O.H. Lowry, N.J. Rosebrough, A.L. Farr, R.J. Randall, Protein measurement with the Folin phenol reagent, J. Biol. Chem. 193 (1951) 265-275.

25. M. Dubois, K.A. Gilles, J.K. Hamilton, P.A. Rebers, F. Smith, Colorimetric method for determination of sugars and related substances. Anal. Chem. 28 (1956) 350-356.

26. E.L. Miller, A.P. Bimbo, D.E. Walters, S.M. Barlow, B. Sheridan, Determination of nitrogen solubility in dilute pepsin hydrochloric acid solution of fishmeal: interlaboratory study, J. AOAC Int. 85 (2002) 1374-1381.

27. J. Adler-Nissen, Enzymic hydrolysis of food proteins, Elsevier Applied Science Publishers, (1986).

28. N. Estévez, P. Fuciños, A.C. Sobrosa, L. Pastrana, N. Pérez, M.L. Rúa, Modeling the angiotensinconverting enzyme inhibitory activity of peptide mixtures obtained from cheese whey hydrolysates using concentrationresponse curves, Biotechnol. Prog. 28 (2012) 1197-1206.

29. M.A. Prieto, T. Curran, A. Gowen, J.A. Vázquez, An efficient methodology for quantification of synergy and antagonism in single electron transfer antioxidant assays. Food Res. Int. 67 (2015) 284-298.

30. M.A. Prieto, J.A. Vázquez, M.A. Murado, Crocin bleaching antioxidant assay revisited. Application to microplate to analyse antioxidant and prooxidant activities. Food Chem. 167 (2015) 299-310.

31. P. Bernfeld, Enzymes of starch degradation and synthesis. Adv. Enzymol. 12 (1951) 379-427.

32. M.L. Cabo, M.A. Murado, M.P. González, L. Pastoriza, A method for bacteriocin quantification. J. Appl. Microbiol. 87 (1999) 907-914. 
33. M.A. Murado, M.P. González, J.A. Vázquez, Dose-response relationships: an overview, a generative model and its application to the verification of descriptive models, Enz. Microb. Technol. 31 (2002) 439-455.

34. J.A. Vázquez, M.A. Murado, Mathematical tools for objective comparison of microbial cultures. Application to evaluation of 15 peptones for lactic acid bacteria productions, Biochem. Eng. J. 39 (2008) 276-287.

35. Z. Khiari, D. Rico, A.B. Martin-Diana, C. Barry-Ryan, Valorization of fish byproducts: rheological, textural and microstructural properties of mackerel skin gelatins, J. Mater. Cycles Waste Manag. 19 (2017) 180-191.

36. Z. Khiari, D. Rico, A.B. Martin-Diana, C. Barry-Ryan, Characterization of blue whiting skin gelatines extracted after pretreatment with different organic acids. J. Aquatic Food Product. Tech. 24 (2015) 546-555.

37. Z. Khiari, D. Rico, A.B. Martin-Diana, C. Barry-Ryan, Comparison between gelatines extracted from mackerel and blue whiting bones after different pretreatments, Food Chem. 139 (2013) 347-354.

38. A.P. Simopoulos, The importance of the ratio of omega-6/omega-3 essential fatty acids, Biomed. Pharmacother. 56 (2002) 365-79.

39. A.P. Simopoulos, Omega-3 fatty acids in inflammation and autoimmune diseases, J. Am. Coll. Nutr. 21 (2002) 495-505.

40. A.P. Simopoulos, J.J. DiNicolantonio, Mediterranean diet: $\omega-6$ and $\omega-3$ fatty acids and diabetes, Am. J. Clin. Nutr. 106 (2017) 953-954.

41. P.E. Romotowska, M.G. Karlsdóttir, M. Gudjónsdóttir, H.G. Kristinsson, S. Arason, Seasonal and geographical variation in chemical composition and lipid stability of Atlantic mackerel (Scomber scombrus) caught in Icelandic waters, J. Food Comp. Anal. 49 (2016) 9-18.

42. P.E. Romotowska, M.G. Karlsdottir, M. Gudjonsdottir, H.G. Kristinsson, S. Arason, Influence of feeding state and frozen storage temperature on the lipid stability of Atlantic mackerel (Scomber scombrus), Int. J. Food Sci. Tech. 51 (2016) 1711-1720.

43. A. Aksnes, B. Hope, E. Jönsson, B.T. Björnsson, S. Albrektsen, Sizefractionated fish hydrolysate as feed ingredient for rainbow trout (Oncorhynchus mykiss) fed high plant protein diets. I: Growth, growth regulation and feed utilization, Aquaculture 261 (2006) 305-317.

44. O. Martínez-Alvarez, S. Chamorro, A. Brenes, Protein hydrolysates from animal processing by-products as a source of bioactive molecules with interest in animal feeding: A review, Food Res. Int. 73 (2015) 204-212. 
45. J.C. Swanepoel, N.J. Goosen, Evaluation of fish protein hydrolysates in juvenile African catfish (Clarias gariepinus) diets, Aquaculture 496 (2018) 262269.

46. World Health Organization (WHO), Protein and amino acid requirements in human nutrition : report of a joint FAO/WHO/UNU expert consultation. WHO Library Cataloguing-in-Publication Data (2007).

47. R. Pérez-Gálvez, P.J. García-Moreno, R. Morales-Medina, A. Guadix, E.M. Guadix, Bile acid binding capacity of fish protein hydrolysates from discard species of the West Mediterranean Sea, Food Funct. 6 (2015) 1261.

48. J.A. Vázquez, P. Ramos, J. Valcarcel, L.T. Antelo, R. Novoa-Carballal, R.L. Reis, R.I. Pérez-Martín, An integral and sustainable valorisation strategy of squid pen byproducts, J. Clean. Prod. 201 (2018) 207-218.

49. M.C. Gomez-Guillen, B. Gimenez, M.E. Lopez-Caballero, M.P. Montero, Functional and bioactive properties of collagen and gelatin from alternative sources: A review, Food Hydrocoll. 25 (2011) 1813-1827.

50. A. Moure, J.M. Cruz, D. Franco, M.J. Núñez, J.C. Parajó, Natural antioxidants from residual sources, Food Chem. 72 (2001) 145-171.

51. A.A.J. Carneiro, I.C.F.R. Ferreira, M. Dueñas, L. Barros, R. Da Silva, E. Gomes, C. Santos-Buelga, Chemical composition and antioxidant activity of dried powder formulations of Agaricus blazei and Lentinus edodes, Food Chem. 138 (2013) 2168-2173.

52. R.G.D. Cruz, L. Beney, P. Gervais, S.P.D. Lira, T.M.F.D.S. Vieira, S. Dupont, Comparison of the antioxidant property of acerola extracts with synthetic antioxidants using an in vivo method with yeasts, Food Chem. 277 (2019) 698-705.

53. A. Taheri, K.H.S. Farvin, C. Jacobsen, C.P. Baron, Antioxidant activities and functional properties of protein and peptide fractions isolated from salted herring brine, Food Chem.142 (2014) 318-326.

54. C.B. Ahn, J.G. Kim, J.Y. Je, Purification and antioxidant properties of octapeptide from salmon byproduct protein hydrolysate by gastrointestinal digestion, Food Chem. 147 (2014) 78-83.

55. W.H. Zhao, C.F. Chi, Y.Q. Zhao, B. Wang, Preparation, physicochemical and antioxidant properties of acid- and pepsin-soluble collagens from the swim bladders of miiuy croaker (Miichthys miiuy), Marine Drugs 16 (2018) 161.

56. M. Blanco, C.G. Sotelo, M.J. Chapela, R.I. Pérez-Martín, Towards sustainable and efficient use of fishery resources: present and future trends, Trends Food Sci. Technol., 18 (2007) 29-36. 
57. S. Egerton, S. Culloty, J. Whooley, C. Stantone, R.P. Ross, Characterization of protein hydrolysates from blue whiting (Micromesistius poutassou) and their application in beverage fortification. Food Chem. 245 (2018) 698-706.

58. N. Aissaoui, F. Abidi, M.N. Marzouki, ACE inhibitory and antioxidant activities of red scorpionfish (Scorpaena notata) protein hydrolysates, J. Food Sci. Technol. 52 (2005) 7092-7102.

59. N. Aissaoui, F. Abidi, J. Hardouin, Z. Abdelkafi, N. Marrakchi, T. Jouenne, M.N. Marzouki, Two novel peptides with angiotensin I converting enzyme inhibitory and antioxidative activities from Scorpaena notata muscle protein hydrolysate, Biotech. Appl. Biochem. 64 (2017) 201-210.

60. M. Geirsdottir, S. Sigurgisladottir, P.Y. Hamaguchi, G. Thorkelsson, R. Johannsson, H.G. Kristinsson, M.M. Kristjansson, Enzymatic hydrolysis of blue whiting (Micromesistius poutassou); functional and bioactive properties, J. Food Sci. 76 (2011) C14-C20.

61. S. Anastasiadou, M. Papagianni, G. Filiousis, I. Ambrosiadis, P. Koidis, Pediocin SA-1, an antimicrobial peptide from Pediococcus acidilactici NRRL B5627: production conditions, purification and characterization, Bior. Technol. 99 (2008) 5384-5390. 


\section{FIGURE CAPTIONS}

Figure 1. Flowchart of fish discards valorisation including fish mince, gelatin, oil, $\mathrm{FPH}$, marine peptone and LAB productions (highlighted in red color). The box list indicates some of the recovered compounds and the analytes determined in FPHs. LAB: Lactic acid bacteria.

Figure 2. Kinetics of SB and He hydrolysis from fish discards using alcalase. The experimental data (symbols) were fitted to the Weibull Equation (3) (continuous line). Error bars are the confidence intervals for $n=2$ and $\alpha=0.05$.

Figure 3. Culture kinetics of $P$. acidilactici grown on different media formulated with peptones obtained from SB (top) and He (bottom) of fish discards and MRS medium as control. Experimental data of biomass $(X)$, lactic acid ( $L a)$, acetic acid $(A a)$ and pediocin $(B T)$ were fitted to the Eq. (5). Reducing sugars (Rs) and proteins (Pr) uptakes were also shown. The confidence intervals of experimental data (for two replicates) were in all cases less than $10 \%$ of the experimental mean values and omitted for clarity. 


\section{TABLE CAPTIONS}

Table 1. Characteristics of gelatin recovered from SB by-products of fish discards. Pro: Proline. OHPro: hydroxyproline. ND: no detected. Showed errors are the confidence intervals for $n=2$ and $\alpha=0.05$.

Table 2. Mass balances and proximal analysis of the products obtained from alcalase hydrolysis of fish discards by-products. Showed errors are the confidence intervals for $n=2$ and $\alpha=0.05$. $m_{b}$ : percentage of the bones recovered; $V_{\text {oil }}$ : percentage of oil recovered; $V_{\text {dig }}$ : percentage of the digestion/liquefaction of the solid by-products to the liquid phase; Prs: Total soluble protein determined by Lowry; TS: Total sugars; Dig: Digestibility; Pr-tN: Total protein determined as total nitrogen x 6.25; H: Humidity; Ash: Ashes; OM: Organic matter.

Table 3. Content of fatty acids (as \%) from oils recovered from fish discards byproducts. Acronyms are defined in Table 2. Showed errors are the confidence intervals for $n=2$ and $\alpha=0.05$.

Table 4. Kinetic parameters and confidence intervals obtained from Weibull equation [1] modeling the time course of the hydrolysis degree $(H)$ of fish discards by-products mediated by alcalase. Determinaton coefficients $\left(R^{2}\right)$ and p-values are also showed.

Table 5. Antioxidant activities of FPHs obtained from fish discards by-products. Showed errors are the confidence intervals for $n=2$ and $\alpha=0.05$.

Table 6. Antihypertensive activities of FPHs obtained from fish discards byproducts. Showed errors are the confidence intervals for $n=2$ and $\alpha=0.05$.

Table 7. Numerical values and confidence intervals for parameters derived from logistic equation applied for $P$. acidilactici productions. $\mathrm{R}^{2}$ is the determination coefficient among experimental and predicted data. The production yields ( $Y_{P / R s}$ and $\left.Y_{P / P r}\right)$ are also calculated. NS: not signficant. MRS 1 and MRS 2 were the controls for each set of kinetic runs (SBP and HeP), respectively. 


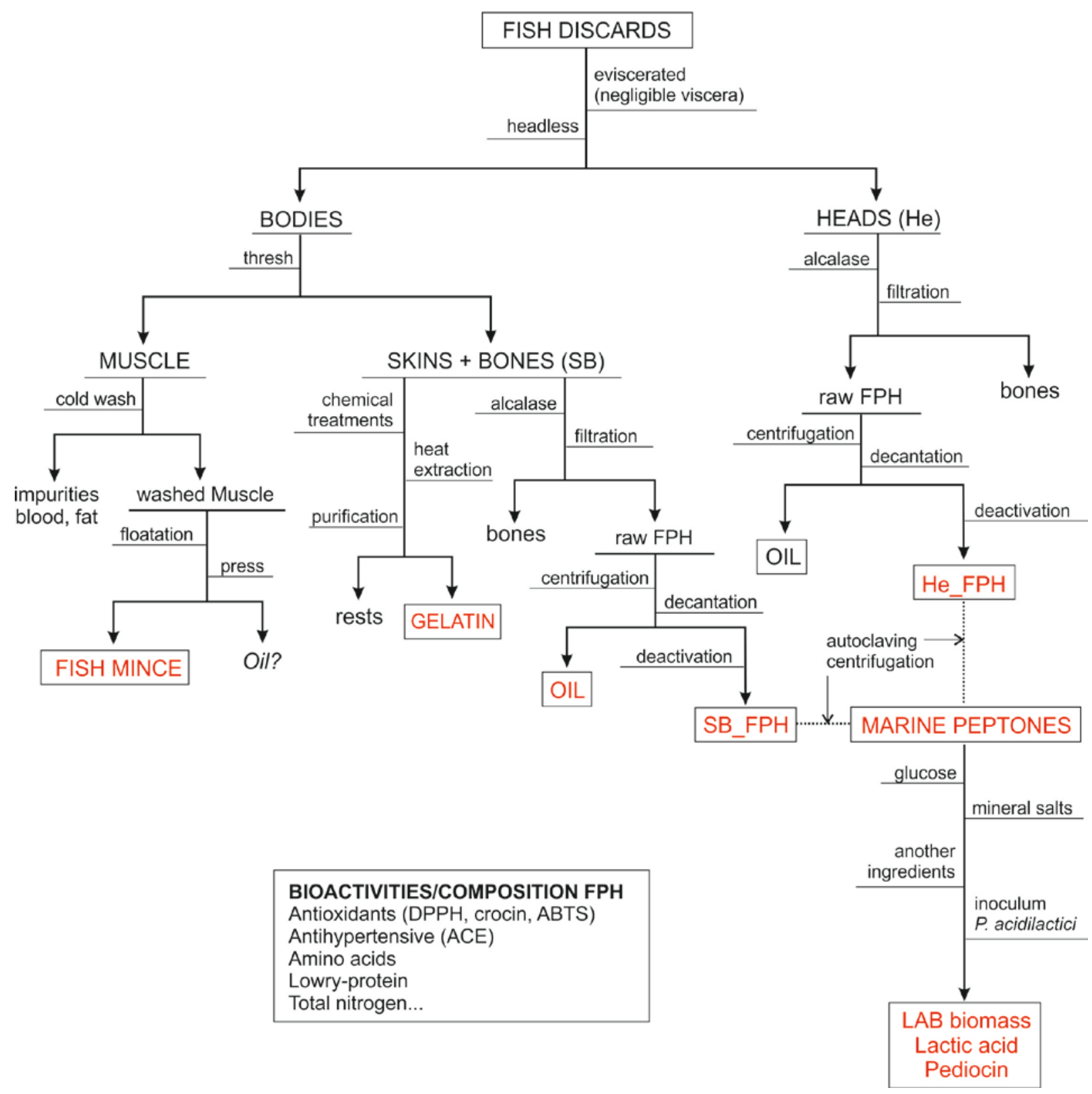

Figure 1. Flowchart of fish discards valorisation including fish mince, gelatin, oil, FPH, marine peptone and LAB productions (highlighted in red color). The box list indicates some of the recovered compounds and the analytes determined in FPHs. LAB: Lactic acid bacteria. 

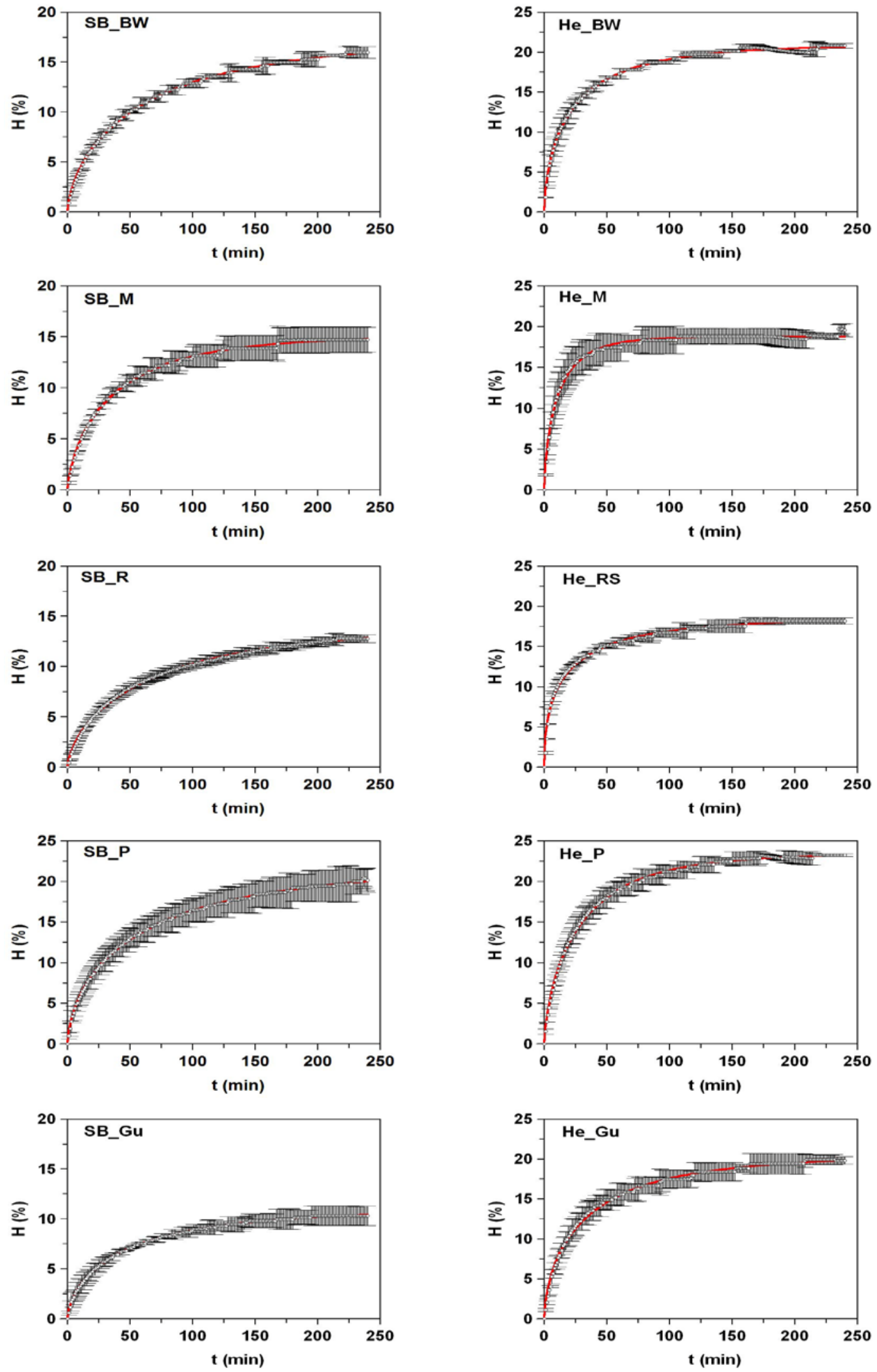

Figure 2. Kinetics of SB and He hydrolysis from fish discards using alcalase. The experimental data (symbols) were fitted to the Weibull Equation (3) (continuous line). Error bars are the confidence intervals for $n=2$ and $\alpha=0.05$. 
Skin/Bone peptones (SBP)
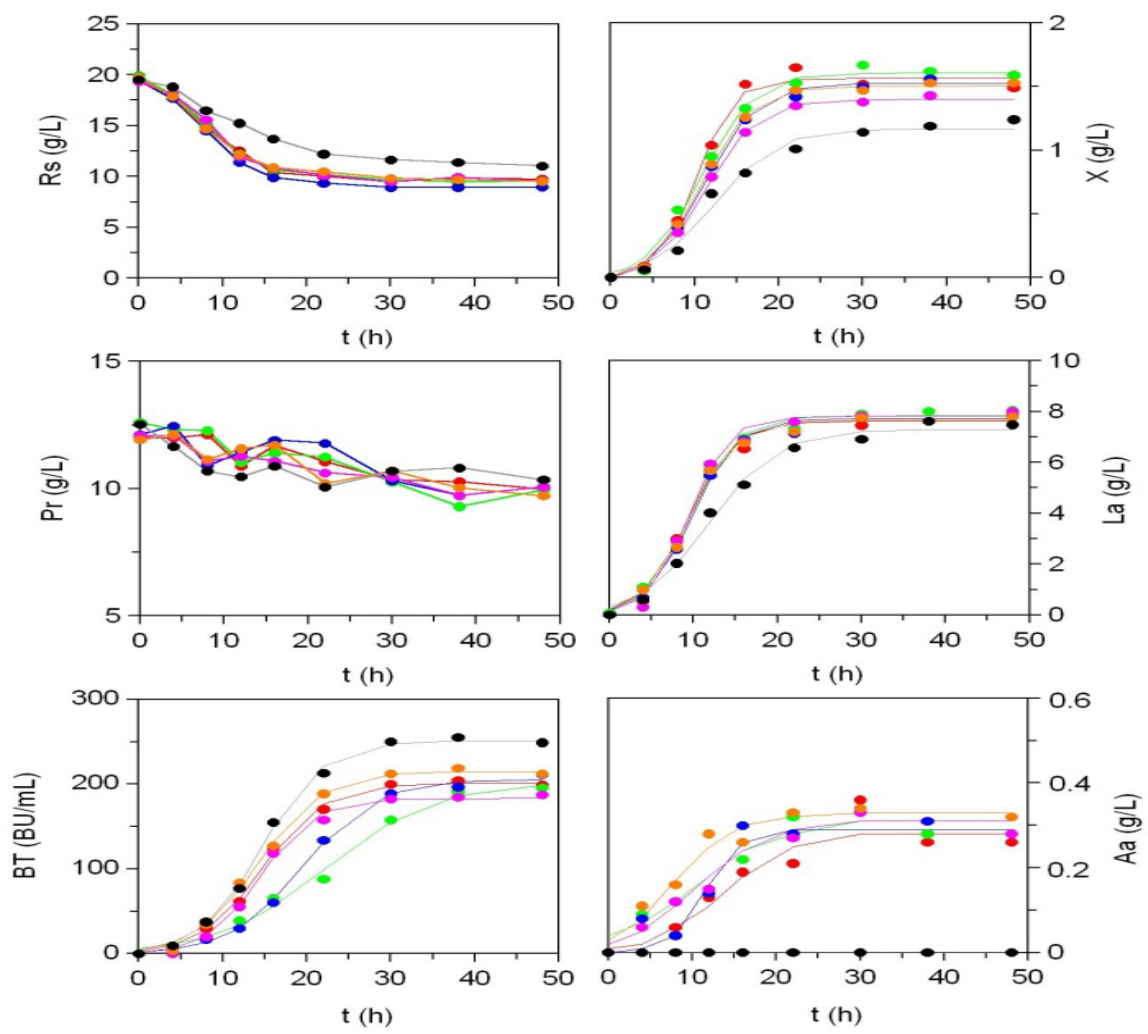

Head peptones (HeP)
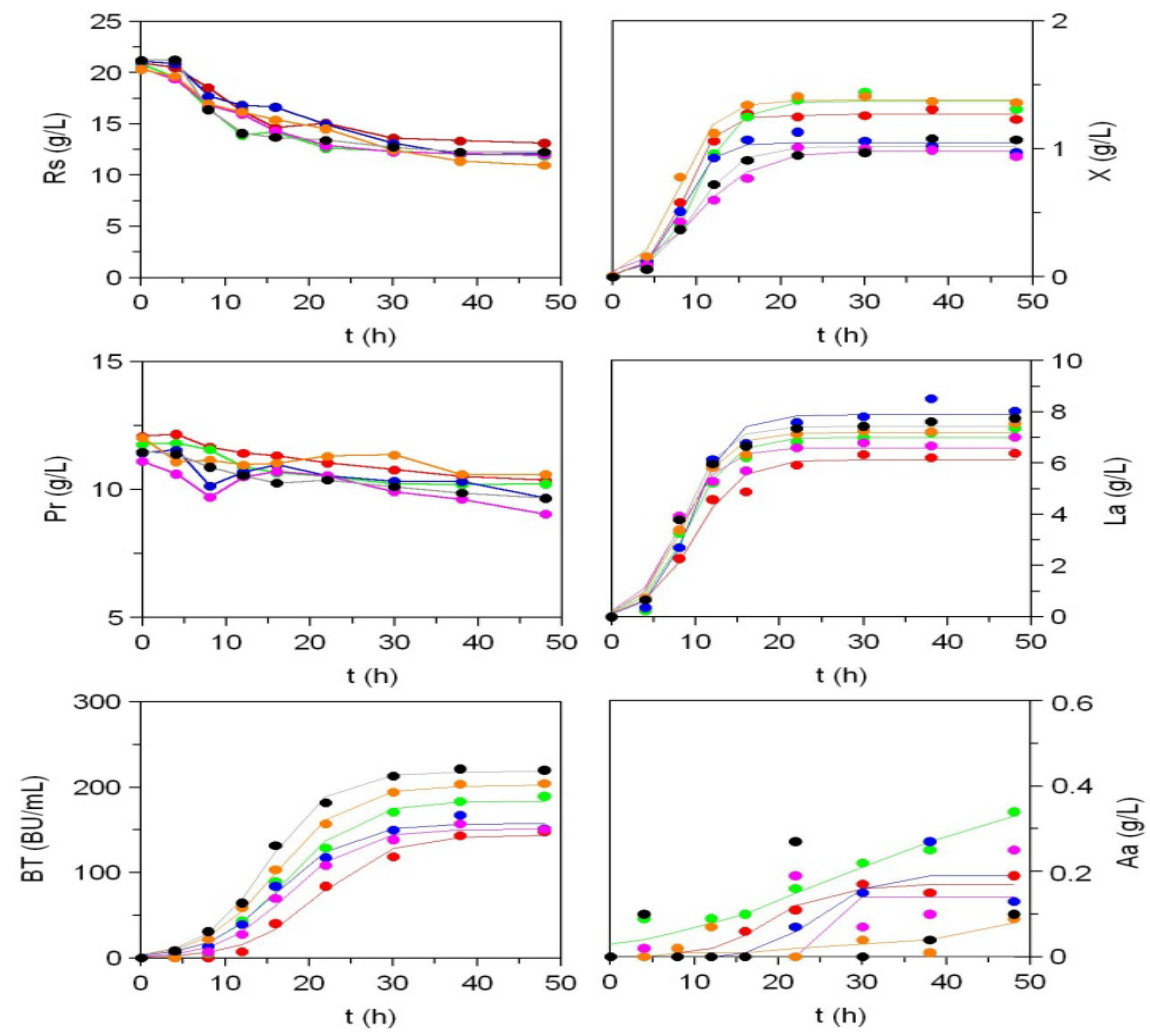

: SBP_BW and HeP_BW; 0 : SBP_RS and HeP_RS; $:$ SBP_M and

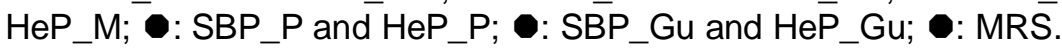

Figure 3. Culture kinetics of $P$. acidilactici grown on different media formulated with peptones obtained from SB (top) and He (bottom) of fish discards and MRS medium as 
control. Experimental data of biomass $(X)$, lactic acid $(L a)$, acetic acid $(A a)$ and pediocin (BT) were fitted to the Eq. (5). Reducing sugars (Rs) and proteins (Pr) uptakes were also shown. The confidence intervals of experimental data (for two replicates) were in all cases less than $10 \%$ of the experimental mean values and omitted for clarity. 
Table 1. Characteristics of gelatin recovered from SB by-products of fish discards. Pro: Proline. OHPro: hydroxyproline. ND: no detected. Showed errors are the confidence intervals for $n=2$ and $\alpha=0.05$. Different letters in each column means significant difference between fish discards $(p<0.05)$.

\begin{tabular}{lccc}
\hline & $\begin{array}{c}\text { Y } \\
\text { (\%. w/w fresh skin) }\end{array}$ & $\begin{array}{c}\text { Gel Strength } \\
\text { (bloom) }\end{array}$ & $\begin{array}{c}\text { Pro + OHPro } \\
\text { (\%) }\end{array}$ \\
\hline Blue whiting (BW) & $0.23 \pm 0.05^{\mathrm{b}}$ & $\mathrm{ND}$ & $15.8 \pm 0.1^{\mathrm{b}}$ \\
Mackerel (M) & $0.69 \pm 0.33^{\mathrm{a}}$ & $\mathrm{ND}$ & $17.3 \pm 0.2^{\mathrm{a}}$ \\
Red scorpionfish (RS) & $0.28 \pm 0.11^{\mathrm{a}}$ & $\mathrm{ND}$ & $15.7 \pm 0.3^{\mathrm{b}}$ \\
Pouting (P) & $0.56 \pm 0.25^{\mathrm{a}}$ & $16.1 \pm 0.6$ & $16.9 \pm 0.2^{\mathrm{a}}$ \\
Gurnard (Gu) & - & - & - \\
\hline
\end{tabular}


Table 2. Mass balances and proximal analysis of the products obtained from alcalase hydrolysis of fish discards by-products. Showed errors are the confidence intervals for $n=2$ and $\alpha=0.05 . m_{b}$ : percentage of the bones recovered; $V_{\text {oil }}$ : percentage of oil recovered; $\mathrm{V}_{\text {dig }}$ : percentage of the digestion/liquefaction of the solid by-products to the liquid phase; Prs: Total soluble protein determined by Lowry; TS: Total sugars; Dig: Digestibility; Pr-tN: Total protein determined as total nitrogen x 6.25; Hu: Humidity; Ash: Ashes; OM: Organic matter. Different letters in each selected column means significant difference between FPH samples ( $p<$ 0.05).

\begin{tabular}{|c|c|c|c|c|c|c|c|c|c|c|}
\hline FPH & $\mathrm{m}_{\mathrm{b}}(\%)$ & $V_{\text {oil }}(\%)$ & $\mathrm{V}_{\text {dig }}(\%)$ & Prs (g/L) & Pr-tN (g/L) & TS (g/L) & Dig (\%) & $\mathrm{Hu}(\%)$ & Ash (\%) & OM (\%) \\
\hline SB_BW & $17.0 \pm 0.2^{b}$ & & $98.1 \pm 0.3^{a}$ & $44.8 \pm 3.1^{a}$ & $45.4 \pm 2.0^{a}$ & $0.65 \pm 0.06$ & $93.4 \pm 0.4^{a b}$ & $93.9 \pm 0.0$ & $0.9 \pm 0.0$ & $5.2 \pm 0.0$ \\
\hline SB_M & $13.8 \pm 0.4^{c}$ & $16.1 \pm 3.2^{\mathrm{a}}$ & $88.8 \pm 0.6^{d}$ & $35.7 \pm 2.4^{b}$ & $37.7 \pm 3.3^{b}$ & $1.61 \pm 0.50$ & $94.4 \pm 2.7^{a}$ & $94.0 \pm 0.6$ & $0.9 \pm 0.3$ & $5.1 \pm 0.9$ \\
\hline SB_RS & $29.0 \pm 2.9 a$ & $0.21 \pm 0.03^{e}$ & $92.4 \pm 0.3^{b}$ & $39.7 \pm 3.6^{\mathrm{ab}}$ & $41.4 \pm 2.3^{a b}$ & $0.74 \pm 0.16$ & $94.4 \pm 1.0^{a}$ & $93.7 \pm 0.0$ & $1.3 \pm 0.8$ & $5.0 \pm 0.8$ \\
\hline SB_P & $16.3 \pm 1.3^{b}$ & - & $96.2 \pm 3.8^{a}$ & $42.7 \pm 4.0^{a}$ & $42.9 \pm 0.6^{a}$ & $0.45 \pm 0.09$ & $95.8 \pm 1.1^{\mathrm{a}}$ & $93.4 \pm 0.5$ & $0.9 \pm 0.1$ & $5.7 \pm 0.4$ \\
\hline SB_Gu & $15.0 \pm 1.0^{b}$ & $4.35 \pm 0.69 d$ & $94.5 \pm 6.1^{\mathrm{a}}$ & $39.7 \pm 2.7^{\mathrm{ab}}$ & $41.6 \pm 2.1^{\mathrm{ab}}$ & $0.92 \pm 0.07$ & $92.7 \pm 1.1^{b}$ & $92.5 \pm 0.0$ & $1.5 \pm 0.1$ & $6.0 \pm 0.1$ \\
\hline He_BW & $13.8 \pm 0.3^{c}$ & $0.44 \pm 0.13^{e}$ & $86.5 \pm 1.9 \mathrm{~d}$ & $34.7 \pm 3.4^{b}$ & $35.9 \pm 1.1^{b}$ & $0.79 \pm 0.01$ & $92.3 \pm 0.5^{b}$ & $94.1 \pm 0.0$ & $0.8 \pm 0.1$ & $5.1 \pm 0.1$ \\
\hline He_M & $18.3 \pm 2.3^{b}$ & $10.1 \pm 0.5^{b}$ & $85.5 \pm 0.9 d$ & $31.4 \pm 2.8^{b}$ & $35.4 \pm 2.8^{b}$ & $0.89 \pm 0.04$ & $89.6 \pm 1.3^{b}$ & $93.8 \pm 0.1$ & $1.0 \pm 0.0$ & $5.3 \pm 0.1$ \\
\hline He_RS & $13.2 \pm 0.5^{c}$ & $6.7 \pm 0.5^{c}$ & $87.0 \pm 1.9 d$ & $39.2 \pm 1.5^{\mathrm{ab}}$ & $39.6 \pm 1.6^{\mathrm{ab}}$ & $1.25 \pm 0.06$ & $89.7 \pm 0.9^{b}$ & $93.4 \pm 0.1$ & $0.9 \pm 0.0$ & $5.8 \pm 0.1$ \\
\hline He_P & $13.4 \pm 1.0^{c}$ & - & $90.0 \pm 0.2^{c}$ & $39.6 \pm 0.4^{a b}$ & $39.3 \pm 1.2^{\mathrm{ab}}$ & $0.68 \pm 0.05$ & $91.7 \pm 0.7^{b}$ & $94.4 \pm 0.0$ & $0.8 \pm 0.1$ & $4.8 \pm 0.3$ \\
\hline He_Gu & $16.4 \pm 0.6^{b}$ & $6.2 \pm 1.1^{c}$ & $84.0 \pm 0.3^{e}$ & $33.5 \pm 5.8^{b}$ & $35.2 \pm 0.2^{b}$ & $1.45 \pm 0.26$ & $90.7 \pm 0.3^{b}$ & $93.9 \pm 0.1$ & $0.9 \pm 0.1$ & $5.3 \pm 0.5$ \\
\hline
\end{tabular}

SB_BW: skin/bones of blue whiting; SB_RS: skin/bones of red scorpionfish; SB_P: skin/bones of pouting; SB_M: skin/bones of mackerel, SB Gu: skin/bones of gurnard, He BW: heads of blue whiting, He M: heads of mackerel, He RS: heads of red scorpionfish, He Gu: heads of gurnard. 
Table 3. Content of fatty acids (as \%) from oils recovered from fish discards byproducts. Acronyms are defined in Table 2. Showed errors are the confidence intervals for $n=2$ and $\alpha=0.05$. Different letters in each row means significant difference between the selected fatty acids $(p<0.05)$.

\begin{tabular}{|c|c|c|c|c|c|c|c|}
\hline Formula & Fatty acids & SB_M & He_Gu & He_M & SB_Gu & He_RS & He_BW \\
\hline C14:0 & Myristic acid & $5.36 \pm 0.32$ & $4.33 \pm 0.26$ & $3.76 \pm 0.20$ & $3.07 \pm 0.14$ & $2.54 \pm 0.12$ & $2.47 \pm 0.19$ \\
\hline C14:1 & Myristoleic acid & $0.30 \pm 0.03$ & $0.21 \pm 0.02$ & $0.08 \pm 0.00$ & $0.21 \pm 0.02$ & $0.12 \pm 0.04$ & $0.32 \pm 0.08$ \\
\hline C15:0 & Pentadecanoic acid & $0.83 \pm 0.06$ & $0.47 \pm 0.03$ & $0.57 \pm 0.05$ & $0.38 \pm 0.02$ & $0.32 \pm 0.03$ & $0.41 \pm 0.05$ \\
\hline C15:1 & Pentadecenoic acid & - & - & $9.26 \pm 0.45$ & $7.99 \pm 0.27$ & $7.79 \pm 0.31$ & $9.04 \pm 0.24$ \\
\hline C16:0 & Palmitic acid & $19.56 \pm 0.76^{a}$ & $16.85 \pm 0.65^{b}$ & $13.94 \pm 0.39 c$ & $12.53 \pm 0.18^{d}$ & $11.97 \pm 0.25^{e}$ & $13.91 \pm 0.15^{c}$ \\
\hline C16:1n7c & Palmitoleic acid & $5.84 \pm 0.33$ & $9.04 \pm 0.50$ & $8.79 \pm 0.62$ & $13.12 \pm 0.39$ & $10.15 \pm 0.37$ & $6.71 \pm 0.30$ \\
\hline C17:0 & Heptadecanoic acid & $0.66 \pm 0.05$ & $0.42 \pm 0.03$ & $0.50 \pm 0.02$ & $0.30 \pm 0.04$ & $0.26 \pm 0.03$ & $0.36 \pm 0.05$ \\
\hline C17:1 & Heptadecanoleic acid & $0.85 \pm 0.09$ & $0.70 \pm 0.07$ & $0.46 \pm 0.03$ & $0.35 \pm 0.01$ & $0.25 \pm 0.02$ & $0.37 \pm 0.04$ \\
\hline C18:0 & Stearic acid & $3.62 \pm 0.45$ & $3.40 \pm 0.42$ & $2.64 \pm 0.18$ & & $3.31 \pm 0.29$ & $3.11 \pm 0.21$ \\
\hline $\mathrm{C} 18: 1 \mathrm{n} 9 \mathrm{c}, \mathrm{t}$ & Oleic acid & $18.89 \pm 0.91 \mathrm{e}$ & $23.08 \pm$ & $22.67 \pm 0.75^{d}$ & 26.66 & 38.89 & $28.85 \pm 1.15^{b}$ \\
\hline C18:2n6c,t & Linoleic acid & $1.32 \pm 0.28$ & $0.90 \pm 0.19$ & $2.04 \pm 0.08$ & $1.61 \pm 0.12$ & $1.48 \pm 0.15$ & $1.93 \pm 0.21$ \\
\hline C20:0 & Arachidic acid & & $0.16 \pm 0.04$ & 0.27 & & & .05 \\
\hline C18:3n3 & Linolen & $1.04 \pm 0.17$ & $0.53 \pm 0.09$ & $0.97 \pm 0.06$ & $0.39 \pm 0.02$ & $0.34 \pm 0.00$ & $0.54 \pm 0.10$ \\
\hline C18:4n3 & Stearidonic acid & $2.61 \pm 0.64$ & $0.88 \pm 0.22$ & - & & - & - \\
\hline C18:3n6 & $\gamma$-Linolenic acid & - & - & $1.29 \pm 0.11$ & $0.54 \pm 0.09$ & $0.07 \pm 0.03$ & $0.73 \pm 0.09$ \\
\hline C20:1n9 & Eicose & $3.32 \pm 0.81$ & $2.28 \pm 0.56$ & $2.79 \pm 0.31$ & $1.53 \pm 0.14$ & $1.06 \pm 0.20$ & $2.71 \pm 0.18$ \\
\hline C20:4n3 & Eicos & $0.87 \pm 0.07$ & $0.60 \pm 0.05$ & - & & - & - \\
\hline C20:3n6 & -linolenic & - & - & $0.39 \pm 0.15$ & $0.05 \pm 0.02$ & $0.19 \pm 0.03$ & $0.58 \pm 0.02$ \\
\hline C20:4n6 & Arachidonic acid & $3.55 \pm 0.65$ & $1.60 \pm 0.29$ & $0.82 \pm 0.28$ & $0.76 \pm 0.08$ & $0.83 \pm 0.09$ & $0.65 \pm 0.10$ \\
\hline$C 20: 5 n 3$ & Eicosa & $10.29 \pm 0.83^{a}$ & $9.11 \pm 0.73^{a}$ & $10.37 \pm 0.45^{a}$ & $8.48 \pm 0.22^{b}$ & $4.86 \pm 0.25^{d}$ & $6.53 \pm 0.35^{c}$ \\
\hline $\mathrm{C} 21: 4 \mathrm{n} 3$ & Henei & & & $1.90 \pm 0.25$ & $1.66 \pm 0.20$ & $3.84 \pm 0.21$ & $1.65 \pm 0.11$ \\
\hline C21:5n3 & Heneicosapentaenoic acid (HPA) & $0.53 \pm 0.06$ & $0.34 \pm 0.04$ & - & 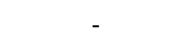 & - & - \\
\hline C22:0 & Docosanoic acid & - & - & $0.77 \pm 0$ & $0.14 \pm C$ & $0.10 \pm 0.03$ & $0.15 \pm 0.00$ \\
\hline $\mathrm{C} 22: 2 \mathrm{n}$ & Docos & - & - & $0.39 \pm 0.05$ & $0.31 \pm 0.02$ & $0.14 \pm 0.01$ & $0.29 \pm 0.02$ \\
\hline C22:5n6 & Docos & $0.25 \pm 0.01$ & $0.21 \pm 0.01$ & - & - & - & - \\
\hline C22:5n3 & Docosapentaenoic acid (DPA) & $1.74 \pm 0.23$ & $2.10 \pm 0.28$ & - & - & - & - \\
\hline \multirow[t]{4}{*}{ C22:6n3 } & Docosahexaenoic acid (DHA) & $11.69 \pm 0.46^{d}$ & $11.80 \pm 0.47 \mathrm{~d}$ & $14.70 \pm 0.35 \mathrm{~b}$ & $12.73 \pm 0.41^{c}$ & $7.65 \pm 0.49 \mathrm{e}$ & $16.72 \pm 0.74^{a}$ \\
\hline & Others & $6.82 \pm 0.99$ & $5.16 \pm 0.75$ & $1.66 \pm 0.40$ & $4.60 \pm 0.88$ & $3.64 \pm 0.69$ & $165+016$ \\
\hline & $\mathrm{DH}$ & 21 & 2 & 25. & 21 & 12. & 23.25 \\
\hline & $\mathrm{r}: \omega-3 / \omega-6$ & 5.62 & 9.36 & 5.67 & 7.11 & 6.15 & 6.01 \\
\hline
\end{tabular}


Table 4. Kinetic parameters and confidence intervals obtained from Weibull equation [1] modeling the time course of the hydrolysis degree $(\mathrm{H})$ of fish discard by-products mediated by alcalase. Determinaton coefficients $\left(R^{2}\right)$ and $p$-values are also showed. Different letters in each selected parameter means significant difference between FPH samples $(p<0.05)$.

\begin{tabular}{lcccccc}
\hline \multicolumn{1}{c}{ FPH } & $\boldsymbol{H}_{\boldsymbol{m}}(\%)$ & $\alpha$ (dimensionless) & $\tau(\mathbf{m i n})$ & $\boldsymbol{V}_{\boldsymbol{m}}\left(\% \mathbf{m i n}^{-1}\right)$ & $\mathbf{R}^{2}$ & $\mathrm{p}$-values \\
\hline SB_BW & $17.44 \pm 0.15^{\mathrm{f}}$ & $0.677 \pm 0.010$ & $36.76 \pm 0.74^{\mathrm{b}}$ & $0.111 \pm 0.003^{\mathrm{g}}$ & 0.999 & $<0.005$ \\
SB_M & $15.15 \pm 0.09 \mathrm{~g}$ & $0.721 \pm 0.013$ & $23.08 \pm 0.39^{\mathrm{e}}$ & $0.164 \pm 0.003^{\mathrm{e}}$ & 0.997 & $<0.005$ \\
SB_RS & $14.20 \pm 0.12^{\mathrm{h}}$ & $0.691 \pm 0.009$ & $40.61 \pm 0.77^{\mathrm{a}}$ & $0.084 \pm 0.002^{\mathrm{i}}$ & 0.999 & $<0.005$ \\
SB_P & $22.00 \pm 0.16^{\mathrm{b}}$ & $0.640 \pm 0.007$ & $34.37 \pm 0.59^{\mathrm{c}}$ & $0.142 \pm 0.003^{\mathrm{f}}$ & 0.999 & $<0.005$ \\
SB_Gu & $11.08 \pm 0.05^{\mathrm{i}}$ & $0.657 \pm 0.007$ & $27.51 \pm 0.33^{\mathrm{d}}$ & $0.092 \pm 0.001^{\mathrm{h}}$ & 0.999 & $<0.005$ \\
He_BW & $20.97 \pm 0.10^{\mathrm{c}}$ & $0.627 \pm 0.012$ & $13.51 \pm 0.27^{\mathrm{h}}$ & $0.337 \pm 0.007^{\mathrm{c}}$ & 0.995 & $<0.005$ \\
He_M & $18.80 \pm 0.05^{\mathrm{e}}$ & $0.704 \pm 0.019$ & $6.89 \pm 0.22^{\mathrm{j}}$ & $0.666 \pm 0.015^{\mathrm{a}}$ & 0.990 & $<0.005$ \\
He_RS & $18.78 \pm 0.13^{\mathrm{e}}$ & $0.503 \pm 0.013$ & $9.19 \pm 0.27^{\mathrm{i}}$ & $0.356 \pm 0.010^{\mathrm{b}}$ & 0.993 & $<0.005$ \\
He_P & $23.48 \pm 0.07^{\mathrm{a}}$ & $0.716 \pm 0.009$ & $17.56 \pm 0.20 \mathrm{~g}$ & $0.332 \pm 0.004^{\mathrm{c}}$ & 0.998 & $<0.005$ \\
He_Gu & $20.49 \pm 0.16^{\mathrm{d}}$ & $0.639 \pm 0.015$ & $19.81 \pm 0.46^{\dagger}$ & $0.229 \pm 0.006^{\mathrm{d}}$ & 0.995 & $<0.005$ \\
\hline
\end{tabular}


Table 5. Antioxidant activities of FPHs obtained from fish discards by-products. Showed errors are the confidence intervals for $n=2$ and $\alpha=0.05$. Different letters in each column means significant difference between FPH samples $(p<0.05)$.

\begin{tabular}{lccc}
\hline \multicolumn{1}{c}{ FPH } & DPPH (\%) & ABTS $(\mu \mathrm{g} / \mathrm{mL})$ & Crocin $(\mu \mathrm{g} / \mathrm{mL})$ \\
\hline SB_BW & $17.36 \pm 0.98^{c, d}$ & $9.30 \pm 1.03^{\mathrm{e}}$ & $5.98 \pm 1.43^{\mathrm{b}}$ \\
SB_M & $23.05 \pm 1.52^{\mathrm{c}}$ & $12.45 \pm 1.00^{\mathrm{d}}$ & $5.14 \pm 1.11^{\mathrm{b}}$ \\
SB_RS & $47.05 \pm 3.25^{\mathrm{a}}$ & $22.99 \pm 1.54^{\mathrm{a}}$ & $10.17 \pm 1.22^{\mathrm{a}}$ \\
SB_P & $38.32 \pm 4.35^{\mathrm{b}}$ & $14.64 \pm 0.97^{\mathrm{c}}$ & $8.91 \pm 0.92^{\mathrm{a}}$ \\
SB_Gu & $40.36 \pm 3.25^{\mathrm{b}}$ & $17.43 \pm 1.37^{\mathrm{b}}$ & $9.21 \pm 1.23^{\mathrm{a}}$ \\
He_BW & $13.12 \pm 1.22^{\mathrm{e}}$ & $3.45 \pm 0.68^{\mathrm{f}}$ & - \\
He_M & $18.11 \pm 2.50^{\mathrm{c}, \mathrm{d}}$ & $8.09 \pm 0.43^{\mathrm{e}}$ & $3.32 \pm 0.49^{\mathrm{c}}$ \\
He_RS & $6.32 \pm 0.88^{\dagger}$ & - & - \\
He_P & $20.52 \pm 5.16^{\mathrm{c}}$ & $7.95 \pm 1.13^{\mathrm{e}}$ & $5.06 \pm 0.78^{\mathrm{b}}$ \\
He_Gu & $5.98 \pm 4.22^{\dagger}$ & - & - \\
\hline
\end{tabular}

Table 6. Antihypertensive activities of FPHs obtained from fish discards by-products. Showed errors are the confidence intervals for $n=2$ and $\alpha=0.05$. Different letters in each column means significant difference between FPH samples $(p<0.05)$.

\begin{tabular}{lcc}
\hline \multicolumn{1}{c}{ FPH } & $I_{\text {ACE }}(\%)$ & $I_{50}(\mu \mathrm{g} / \mathrm{mL})$ \\
\hline SB_BW & $42.46 \pm 2.07^{\mathrm{b}}$ & - \\
SB_M & $49.59 \pm 6.70^{\mathrm{b}}$ & - \\
SB_RS & $76.79 \pm 8.00^{\mathrm{a}}$ & $226.3 \pm 40.7^{\mathrm{a}}$ \\
SB_P & $69.70 \pm 6.92^{\mathrm{a}}$ & $211.4 \pm 26.8^{\mathrm{a}}$ \\
SB_Gu & $65.20 \pm 5.65^{\mathrm{a}}$ & $151.8 \pm 13.0^{\mathrm{b}}$ \\
He_BW & - & - \\
He_M & $21.30 \pm 1.03^{\mathrm{d}}$ & - \\
He_RS & - & - \\
He_P & $28.06 \pm 1.09^{\mathrm{c}}$ & - \\
He_Gu & - & - \\
\hline
\end{tabular}


Table 7. Numerical values and confidence intervals for parameters derived from logistic equation applied for $P$. acidilactici productions. $\mathrm{R}^{2}$ is the determination coefficient among experimental and predicted data. The production yields $\left(Y_{P / R s}\right.$ and $\left.Y_{P / P r}\right)$ are also calculated. NS: not signficant. MRS 1 and MRS 2 were the controls for each set of kinetic runs (SBP and HeP), respectively. Different letters in each row means significant difference between the selected kinetic parameters $(p<0.05)$.

\begin{tabular}{|c|c|c|c|c|c|c|c|c|c|c|c|c|}
\hline Parameters & SBP_BW & SBP_RS & SBP_M & SBP_P & SBP_Gu & HeP_BW & HeP_RS & HeP_M & HeP_P & HeP_Gu & MRS 1 & MRS 2 \\
\hline \multicolumn{13}{|c|}{ Biomass $(X)$} \\
\hline$X_{m}(\mathrm{~g} / \mathrm{L})$ & $1.57 \pm 0.08^{a}$ & $1.61 \pm 0.08^{a}$ & $1.53 \pm 0.06^{a}$ & $1.40 \pm 0.03^{b}$ & $1.51 \pm 0.04^{a}$ & $1.27 \pm 0.04^{c}$ & $1.37 \pm 0.05^{b}$ & $1.05 \pm 0.05^{e}$ & $0.98 \pm 0.08 \mathrm{e}$ & $1.38 \pm 0.06^{b}$ & $1.17 \pm 0.05^{d}$ & $1.09 \pm 0.06^{\text {de }}$ \\
\hline$V_{x}\left(g^{-1} h^{-1}\right)$ & $0.18 \pm 0.05^{a}$ & $0.13 \pm 0.03^{a}$ & $0.13 \pm 0.03^{a}$ & $0.12 \pm 0.01^{\mathrm{a}}$ & $0.13 \pm 0.02^{\mathrm{a}}$ & $0.16 \pm 0.04 a$ & $0.14 \pm 0.03^{a}$ & $0.14 \pm 0.03^{a}$ & $0.07 \pm 0.03^{b}$ & $0.15 \pm 0.04 a$ & $0.08 \pm 0.03^{b}$ & $0.10 \pm 0.03^{a}$ \\
\hline$\lambda_{x}(\mathrm{~h})$ & $5.80 \pm 1.43^{a}$ & $4.78 \pm 1.73^{a}$ & $5.35 \pm 1.36^{a}$ & $5.48 \pm 0.78^{a}$ & $5.28 \pm 0.86^{a}$ & $4.55 \pm 0.93^{a}$ & $5.19 \pm 1.09 a$ & $4.33 \pm 1.09 a$ & $3.10 \pm 3.00^{a}$ & $3.31 \pm 1.41^{a}$ & $5.17 \pm 1.72^{\mathrm{a}}$ & $4.49 \pm 1.97^{a}$ \\
\hline$Y_{X / R s}(g X / g R s)$ & 0.150 & 0.153 & 0.151 & 0.143 & 0.150 & 0.156 & 0.145 & 0.106 & 0.111 & 0.145 & 0.138 & 0.119 \\
\hline$Y_{X / P r}(g X / g P r)$ & 0.730 & 0.599 & 0.766 & 0.698 & 0.690 & 0.711 & 0.848 & 0.544 & 0.456 & 0.953 & 0.535 & 0.584 \\
\hline $\mathbf{R}^{2}$ & 0.994 & 0.994 & 0.988 & 0.999 & 0.999 & 0.997 & 0.997 & 0.990 & 0.983 & 0.994 & 0.986 & 0.990 \\
\hline \multicolumn{13}{|c|}{ Lactic acid (La) } \\
\hline $\operatorname{Lam}(g / L)$ & $7.62 \pm 0.45^{\mathrm{a}}$ & $7.84 \pm 0.32^{\mathrm{a}}$ & $7.73 \pm 0.36^{a}$ & $7.82 \pm 0.41^{a}$ & $7.65 \pm 0.31^{a}$ & $6.14 \pm 0.49 \mathrm{bc}$ & $7.02 \pm 0.47^{a b}$ & $7.89 \pm 0.51^{\mathrm{a}}$ & $6.60 \pm 0.49 b$ & $7.20 \pm 0.36^{a}$ & $7.30 \pm 0.46^{a}$ & $7.43 \pm 0.40^{\mathrm{a}}$ \\
\hline$V_{L a}\left(g L^{-1} h^{-1}\right)$ & $0.72 \pm 0.23^{a}$ & $0.70 \pm 0.15^{a}$ & $0.73 \pm 0.18^{a}$ & $0.83 \pm 0.25^{a}$ & $0.70 \pm 0.15^{\mathrm{a}}$ & $0.56 \pm 0.24 a$ & $0.70 \pm 0.27 a$ & $0.86 \pm 0.33^{a}$ & $0.67 \pm 0.24 a$ & $0.73 \pm 0.22^{a}$ & $0.46 \pm 0.12^{b}$ & $0.77 \pm 0.25^{a}$ \\
\hline$\lambda_{L a}(h)$ & $4.13 \pm 1.94^{a}$ & $4.02 \pm 1.37^{a}$ & $4.54 \pm 1.50^{a}$ & $4.76 \pm 1.62^{\mathrm{a}}$ & $4.07 \pm 1.33^{a}$ & $4.29 \pm 2.62^{\mathrm{a}}$ & $4.02 \pm 1.33^{a}$ & $4.96 \pm 1.98^{a}$ & $2.95 \pm 2.62^{\mathrm{a}}$ & $3.65 \pm 1.62^{a}$ & $4.04 \pm 2.29 a$ & $3.58 \pm 1.75^{a}$ \\
\hline$Y_{L a / R s}(g L a / g R s)$ & 0.802 & 0.769 & 0.754 & 0.815 & 0.768 & 0.815 & 0.816 & 0.891 & 0.831 & 0.805 & 0.885 & 0.865 \\
\hline$Y_{L a / P r}(\mathrm{gLa} / \mathrm{gPr})$ & 3.90 & 3.01 & 3.84 & 3.97 & 3.53 & 3.71 & 4.78 & 4.55 & 3.41 & 5.29 & 3.42 & 4.25 \\
\hline $\mathbf{R}^{2}$ & 0.991 & 0.995 & 0.994 & 0.993 & 0.995 & 0.984 & 0.988 & 0.989 & 0.980 & 0.993 & 0.993 & 0.992 \\
\hline \multicolumn{13}{|c|}{ Acetic acid (Aa) } \\
\hline$A a_{m}(g / L)$ & $0.28 \pm 0.06$ & $0.31 \pm 0.06$ & $0.29 \pm 0.06$ & $0.31 \pm 0.06$ & $0.33 \pm 0.03$ & $0.17 \pm 0.03$ & $0.38 \pm 0.22$ & $0.20 \pm 0.08$ & $0.15 \pm 0.08$ & 3.97 (NS) & - & - \\
\hline$V_{A a}\left(g L^{-1} h^{-1}\right)$ & $0.72 \pm 0.23$ & $0.70 \pm 0.15$ & $0.73 \pm 0.18$ & $0.83 \pm 0.25$ & $0.70 \pm 0.15$ & $0.56 \pm 0.24$ & $0.70 \pm 0.27$ & $0.86 \pm 0.33$ & $0.21(\mathrm{NS})$ & 0.06 (NS) & - & - \\
\hline$\lambda_{A a}(\mathrm{~h})$ & $0.02 \pm 0.02$ & $0.02 \pm 0.01$ & 0.04 (NS) & $0.02 \pm 0.02$ & $0.02 \pm 0.01$ & $0.01 \pm 0.01$ & $0.01 \pm 0.00$ & 0.02 (NS) & 18.67 (NS) & 77.5 (NS) & - & - \\
\hline$Y_{A a / R s}(g A a / g R s)$ & 0.026 & 0.030 & 0.022 & 0.028 & 0.032 & 0.024 & 0.038 & 0.015 & 0.029 & 0.010 & - & - \\
\hline$Y_{A a / \operatorname{Pr}}(\mathrm{gAa} / \mathrm{gPr})$ & 0.126 & 0.116 & 0.110 & 0.138 & 0.145 & 0.110 & 0.221 & 0.075 & 0.120 & 0.066 & - & - \\
\hline $\mathbf{R}^{2}$ & 0.917 & 0.924 & 0.901 & 0.965 & 0.963 & 0.968 & 0.923 & 0.862 & 0.697 & 0.443 & - & - \\
\hline \multicolumn{13}{|c|}{ Pediocin (BT) } \\
\hline$B T_{m}(B U / m L)$ & $201.0 \pm 6.8^{b}$ & $202.8 \pm 19.7^{b}$ & $205.8 \pm 7.5^{b}$ & $183.2 \pm 8.1^{c}$ & $214.9 \pm 8.8^{b}$ & $144.2 \pm 12.8^{d}$ & $184.1 \pm 15.2^{c}$ & $157.7 \pm 11.7^{\mathrm{d}}$ & $150.9 \pm 10.5^{d}$ & $202.5 \pm 9.3^{b}$ & $251.3 \pm 8.5^{a}$ & $218.6 \pm 7.7^{b}$ \\
\hline$V_{B T}\left(B U \mathrm{~mL}^{-1} \mathrm{~h}^{-1}\right)$ & $13.7 \pm 2.1^{\mathrm{ab}}$ & $7.9 \pm 1.7 c$ & $12.0 \pm 1.6^{b}$ & $14.5 \pm 3.1^{\mathrm{ab}}$ & $14.2 \pm 2.5^{\mathrm{ab}}$ & $8.3 \pm 2.6 c$ & $10.8 \pm 3.4^{\mathrm{bc}}$ & $9.4 \pm 2.7 c$ & $9.3 \pm 2.5^{c}$ & $12.2 \pm 2.2^{b}$ & $17.2 \pm 2.6^{a}$ & $14.5 \pm 2.2^{\mathrm{ab}}$ \\
\hline$\lambda_{B T}(\mathrm{~h})$ & $7.4 \pm 1.1^{\mathrm{ab}}$ & $9.4 \pm 2.7^{\mathrm{ab}}$ & $10.9 \pm 1.2^{\mathrm{a}}$ & $8.2 \pm 1.4^{\mathrm{ab}}$ & $6.8 \pm 1.4^{\mathrm{bc}}$ & $12.4 \pm 2.7^{a}$ & $8.8 \pm 2.7^{a b}$ & $8.0 \pm 2.5^{\mathrm{ab}}$ & $9.5 \pm 2.2^{\mathrm{a}}$ & $7.9 \pm 1.5^{\mathrm{ab}}$ & $7.4 \pm 1.1^{\mathrm{ab}}$ & $7.4 \pm 1.2^{\mathrm{ab}}$ \\
\hline$Y_{B T / R s}(\mathrm{BU} / \mathrm{mgRs})$ & 20.06 & 18.85 & 20.15 & 19.10 & 20.85 & 18.87 & 21.05 & 16.78 & 17.85 & 21.80 & 29.50 & 24.57 \\
\hline$Y_{B T / P r}(\mathrm{BU} / \mathrm{mgPr})$ & 97.59 & 73.73 & 102.53 & 93.0 & 95.97 & 85.84 & 123.16 & 85.71 & 73.24 & 143.36 & 113.80 & 120.81 \\
\hline $\mathbf{R}^{2}$ & 0.998 & 0.993 & 0.998 & 0.997 & 0.997 & 0.992 & 0.991 & 0.991 & 0.994 & 0.997 & 0.998 & 0.998 \\
\hline
\end{tabular}




\section{SUPPLEMENTARY MATERIAL}

Table S1. Composition of the culture media (in $\mathrm{g} / \mathrm{L}$ ) used for the fermentation of $P$. acidilactici. SBP_BW: culture medium formulated with skin/bone peptone from blue whithing. SBP_RS: culture medium formulated with skin/bone peptone from red scorpionfish. SBP_M: culture medium formulated with skin/bone peptone from mackerel. SBP_P: culture medium formulated with skin/bone peptone from pouting. SBP_Gu: culture medium formulated with skin/bone peptone from gurnard. HeP_BW: culture medium formulated with head peptone from blue whithing. HeP_RS: culture medium formulated with head peptone from red scorpionfish. HeP_M: culture medium formulated with head peptone from mackerel. HeP_P: culture medium formulated with head peptone from pouting. HeP_Gu: culture medium formulated with head peptone from gurnard.

\begin{tabular}{lccccccccccc} 
& SBP_BW & SBP_RS & SBP_M & SBP_P & SBP_Gu & HeP_BW & HeP_RS & HeP_M & HeP_P & HeP_Gu & MRS \\
\hline Glucose & 20 & 20 & 20 & 20 & 20 & 20 & 20 & 20 & 20 & 20 & 20 \\
Yeast extract & 4 & 4 & 4 & 4 & 4 & 4 & 4 & 4 & 4 & 4 & 4 \\
Sodium acetate & 5 & 5 & 5 & 5 & 5 & 5 & 5 & 5 & 5 & 5 & 5 \\
Ammonium citrate & 2 & 2 & 2 & 2 & 2 & 2 & 2 & 2 & 2 & 2 & 2 \\
$\mathrm{~K}_{2} \mathrm{HPO}_{4}$ & 2 & 2 & 2 & 2 & 2 & 2 & 2 & 2 & 2 & 2 & 2 \\
$\mathrm{MgSO}_{4}$ & 0.2 & 0.2 & 0.2 & 0.2 & 0.2 & 0.2 & 0.2 & 0.2 & 0.2 & 0.2 & 0.2 \\
$\mathrm{MnSO}_{4}$ & 0.05 & 0.05 & 0.05 & 0.05 & 0.05 & 0.05 & 0.05 & 0.05 & 0.05 & 0.05 & 0.05 \\
Tween $_{\text {80 }}$ & 1 & 1 & 1 & 1 & 1 & 1 & 1 & 1 & 1 & 1 & 1 \\
Meat extract & - & - & - & - & - & - & - & - & - & - & 8 \\
Bactopeptone & - & - & - & - & - & - & - & - & - & - & 10 \\
Skin Peptone & 10 & 10 & 10 & 10 & 10 & 10 & 10 & 10 & 10 & 10 & - \\
\hline
\end{tabular}

*Soluble proteins (as Lowry-method) at $10 \mathrm{~g} / \mathrm{L}$ in the final media. 
Table S2. Amino acids content of FPHs (\% or g/100 g total amino acids) produced with by-products of skin/bones (SB) and heads $(\mathrm{He})$ from fish discards. OHPro: hydroxyproline. The showed error are the confidence intervals for $\mathrm{n}=2$ and $\alpha=0.05$.

\begin{tabular}{|c|c|c|c|c|c|c|c|c|c|c|}
\hline Amino acids & SB_BW & SB_M & SB_RS & SB_P & SB_Gu & He_BW & He_M & He_RS & $\mathrm{He} \_\mathrm{P}$ & $\mathrm{He} \_\mathrm{Gu}$ \\
\hline Asp & $9.77 \pm 0.05$ & $9.13 \pm 0.03$ & $9.64 \pm 0.05$ & $9.61 \pm 0.08$ & $9.12 \pm 0.50$ & $9.85 \pm 0.10$ & $9.84 \pm 0.32$ & $10.13 \pm 0.04$ & $9.95 \pm 0.08$ & 0.20 \\
\hline Thr & $4.45 \pm 0.19$ & $4.36 \pm 0.08$ & $4.18 \pm 0.06$ & $3.47 \pm 0.11$ & $4.02 \pm 0.11$ & $4.16 \pm 0.14$ & $4.02 \pm 0.39$ & $4.27 \pm 0.06$ & $4.37 \pm 0.23$ & $4.29 \pm 0.06$ \\
\hline Ser & $5.81 \pm 0.10$ & $5.38 \pm 0.11$ & $5.50 \pm 0.09$ & $5.15 \pm 0.01$ & $5.86 \pm 0.11$ & $5.38 \pm 0.25$ & $5.12 \pm 0.36$ & $5.12 \pm 0.07$ & $5.17 \pm 0.49$ & $5.26 \pm 0.66$ \\
\hline Glu & $14.45 \pm 0.24$ & $12.88 \pm 0.26$ & $13.50 \pm 0.01$ & $12.55 \pm 0.18$ & $12.49 \pm 0.01$ & $15.01 \pm 0.61$ & $15.32 \pm 0.57$ & $13.83 \pm 0.08$ & $15.40 \pm 2.48$ & $16.33 \pm 0.67$ \\
\hline Gly & $10.88 \pm 0.30$ & $11.64 \pm 0.07$ & $12.36 \pm 0.35$ & $11.46 \pm 0.16$ & $15.05 \pm 0.08$ & $7.18 \pm 0.34$ & $6.99 \pm 0.48$ & $8.29 \pm 0.16$ & $7.44 \pm 1.83$ & $6.73 \pm 0.45$ \\
\hline Ala & $8.25 \pm 0.33$ & $8.21 \pm 0.05$ & $8.47 \pm 0.19$ & $8.10 \pm 0.05$ & $8.85 \pm 0.10$ & $6.35 \pm 0.01$ & $6.23 \pm 0.31$ & $7.68 \pm 0.05$ & $6.64 \pm 0.67$ & $6.50 \pm 0.40$ \\
\hline Cys & $0.35 \pm 0.03$ & $0.26 \pm 0.01$ & $0.31 \pm 0.01$ & $0.33 \pm 0.00$ & $0.26 \pm 0.02$ & $0.39 \pm 0.09$ & $0.41 \pm 0.06$ & $0.36 \pm 0.01$ & $0.39 \pm 0.01$ & $0.36 \pm 0.04$ \\
\hline Val & $3.88 \pm 0.10$ & $4.03 \pm 0.02$ & $3.27 \pm 0.00$ & $2.93 \pm 0.05$ & $3.30 \pm 0.06$ & $4.20 \pm 0.04$ & $4.23 \pm 0.16$ & $4.21 \pm 0.03$ & $4.21 \pm 0.39$ & $4.12 \pm 0.20$ \\
\hline Met & $3.22 \pm 0.35$ & $3.05 \pm 0.11$ & $3.24 \pm 0.13$ & $3.31 \pm 0.12$ & $3.30 \pm 0.26$ & $3.56 \pm 0.08$ & $3.69 \pm 0.18$ & $3.66 \pm 0.02$ & $3.27 \pm 0.12$ & $3.47 \pm 0.50$ \\
\hline Ile & $2.96 \pm 0.12$ & $3.13 \pm 0.02$ & $2.42 \pm 0.05$ & $2.06 \pm 0.07$ & $2.06 \pm 0.17$ & $3.37 \pm 0.74$ & $3.40 \pm 0.58$ & $3.33 \pm 0.03$ & $3.94 \pm 1.06$ & $3.80 \pm 1.34$ \\
\hline Leu & $6.76 \pm 0.05$ & $6.83 \pm 0.07$ & $6.13 \pm 0.09$ & $5.87 \pm 0.06$ & $5.72 \pm 0.10$ & $7.10 \pm 0.11$ & $7.14 \pm 0.07$ & $7.41 \pm 0.03$ & $7.59 \pm 0.28$ & $7.52 \pm 0.04$ \\
\hline Tyr & $2.87 \pm 0.03$ & $2.81 \pm 0.05$ & $2.76 \pm 0.01$ & $2.64 \pm 0.08$ & $2.29 \pm 0.03$ & $3.72 \pm 0.29$ & $4.13 \pm 0.39$ & $3.13 \pm 0.00$ & $3.42 \pm 0.11$ & $3.77 \pm 0.58$ \\
\hline Phe & $3.97 \pm 0.17$ & $3.86 \pm 0.19$ & $3.98 \pm 0.03$ & $4.00 \pm 0.03$ & $3.70 \pm 0.25$ & $4.16 \pm 0.18$ & $4.49 \pm 0.81$ & $4.79 \pm 0.04$ & $3.86 \pm 0.69$ & $3.26 \pm 0.50$ \\
\hline His & $1.95 \pm 0.00$ & $2.72 \pm 0.25$ & $1.80 \pm 0.00$ & $1.93 \pm 0.02$ & $1.91 \pm 0.05$ & $2.22 \pm 0.41$ & $2.14 \pm 0.69$ & $1.95 \pm 0.01$ & $2.07 \pm 0.56$ & $2.23 \pm 0.18$ \\
\hline Lys & $6.77 \pm 0.13$ & $6.56 \pm 0.07$ & $6.73 \pm 0.06$ & $6.21 \pm 0.33$ & $5.93 \pm 0.32$ & $7.82 \pm 0.06$ & $7.59 \pm 0.10$ & $7.09 \pm 0.06$ & $7.04 \pm 0.45$ & $7.03 \pm 0.43$ \\
\hline Arg & $6.25 \pm 0.05$ & $6.52 \pm 0.11$ & $6.63 \pm 0.09$ & $5.85 \pm 0.18$ & $6.66 \pm 0.42$ & $7.01 \pm 0.15$ & $6.78 \pm 1.19$ & $6.10 \pm 0.03$ & $6.23 \pm 0.10$ & $6.31 \pm 0.26$ \\
\hline OHPro & $1.99 \pm 0.31$ & $2.21 \pm 0.27$ & $2.78 \pm 0.16$ & $9.41 \pm 1.28$ & $3.24 \pm 0.38$ & $4.14 \pm 0.42$ & $3.98 \pm 0.22$ & $4.42 \pm 0.39$ & $4.08 \pm 0.42$ & $4.28 \pm 0.04$ \\
\hline Pro & $5.43 \pm 0.01$ & $6.45 \pm 0.21$ & $6.31 \pm 0.08$ & $5.11 \pm 0.29$ & $6.24 \pm 0.48$ & $4.37 \pm 0.61$ & $4.46 \pm 0.81$ & $4.22 \pm 0.02$ & $4.92 \pm 0.02$ & $4.89 \pm 0.03$ \\
\hline $\operatorname{Pr}(\Sigma a a)(g / L)$ & $43.78 \pm 10.66$ & $39.21 \pm 2.38$ & $41.78 \pm 10.66$ & $42.21 \pm 2.38$ & $44.87 \pm 1.68$ & $37.82 \pm 1.88$ & $37.06 \pm 0.65$ & $40.27 \pm 2.82$ & $39.22 \pm 0.20$ & $36.08 \pm 0.03$ \\
\hline
\end{tabular}



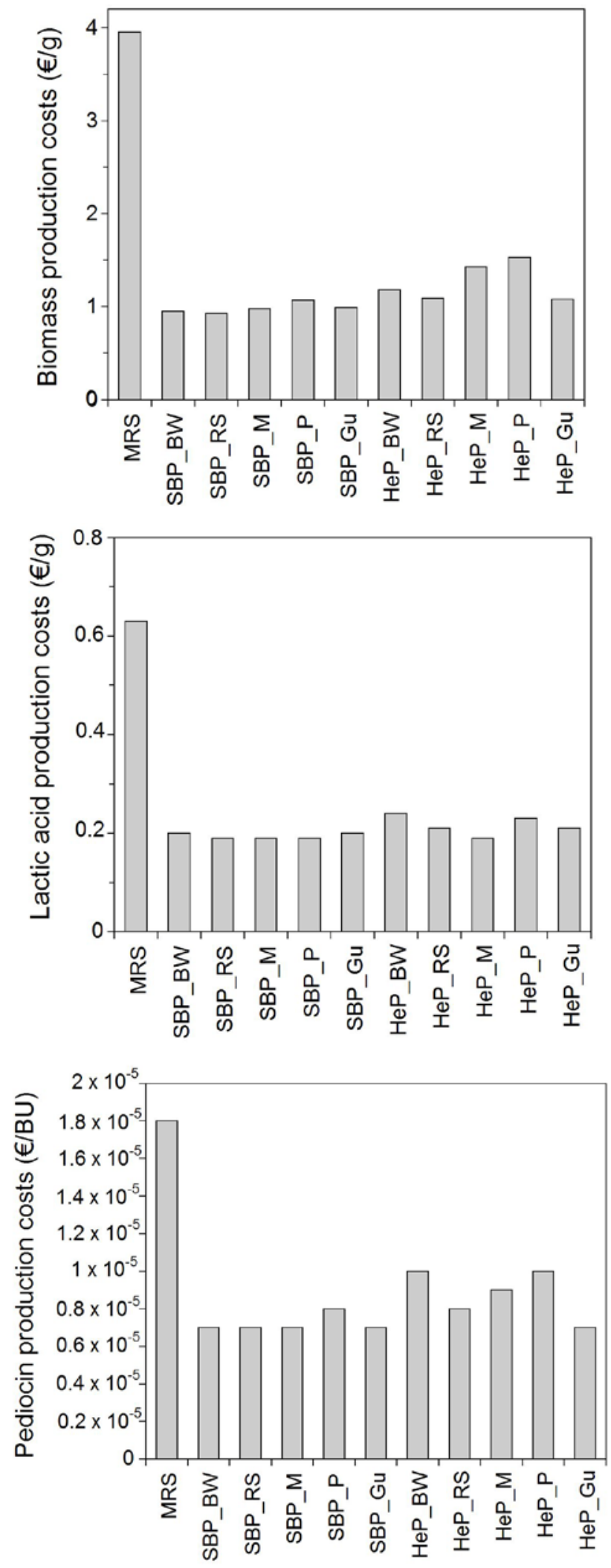

Figure S1. Costs of the bioproductions generated by $P$. acidilactici growing in MRS and alternative media. 